\title{
High-pressure veins in eclogite from New Caledonia and their significance for fluid migration in subduction zones
}

\author{
Carl Spandler*, Jörg Hermann \\ Research School of Earth Sciences, Australian National University, Canberra, 0200, Australia \\ Received 10 June 2005; accepted 4 December 2005 \\ Available online 9 February 2006
}

\begin{abstract}
This paper describes the petrology and geochemistry of high-pressure veins and associated metasomatic selvages that are hosted by eclogite in the Pouébo Eclogite Melange of northern New Caledonia. Isotopic and geochemical evidence indicates that the mafic host rock represents seafloor-altered fractionated MORB that underwent eclogite-facies metamorphism in a subduction zone. Within the host rock are cm-thick garnet-quartz-phengite veins that are enveloped by garnet-poor, omphacite-rich selvages or bleach zones. Petrography, thermometry, oxygen isotope characteristics, and mass balance calculations are used to show that the veins largely formed by fluid-mediated mass transfer from the bleach zones during prograde metamorphism. Minerals in the veins are free of inclusions, but the vein garnets preserve complex chemical zoning features that are not present in the host rock garnets. Vein garnets have Mn and HREE zoning patterns that are indicative of progressive garnet growth during prograde metamorphism, whereas $\mathrm{Mg}$ and $\mathrm{Ca}$ contents reveal prominent sector zoning and fine-scale intergrowth features.

We propose that the veins formed over a prolonged period during subduction by local circulation of fluid that was sourced from prograde dehydration of minerals in the host rock. Fluid circulation may have been driven by episodic microcracking/sealing around garnet porphyroblasts, which led to significant mass transfer and progressive vein growth. Mass balance calculations and phengite trace element compositions also require the additional of pelite-derived components to the veins. These components were probably introduced into the veins at conditions close to peak metamorphism via a relatively small external fluid flux.

This model for vein formation is consistent with previous studies that suggest fluid flow in deeply subducted oceanic crust is highly restricted in many cases. The delay of fluid migration after hydrous mineral breakdown may provide an important source of water for arc magmas as free fluid is transported to deeper levels in subduction zones.
\end{abstract}

(C) 2006 Elsevier B.V. All rights reserved.

Keywords: New Caledonia; Eclogite; Veins; Subduction; Fluid flow

\section{Introduction}

The recycling of $\mathrm{H}_{2} \mathrm{O}$ through subduction zones is one of the most fundamental processes affecting the chemical differentiation of Earth. It is now widely

\footnotetext{
* Corresponding author. Tel.: +61 261253414.

E-mail address: Carl.Spandler@anu.edu.au (C. Spandler).
}

accepted that hydrous fluids sourced from subducting slabs not only act as catalysts for arc magma generation but are also responsible for returning significant amounts of volatile and incompatible elements back to the crust. During subduction, hydrothermally altered oceanic crust is expected to undergo extensive dehydration at the blueschist to eclogite-facies transition (Peacock, 1993). Fluids released at this transition are 
commonly assumed to be the major source of water for arc magmas and the major cause of intermediate depth intraslab earthquakes (Hacker et al., 2003). However, recent experimental studies have shown that mafic rocks in most subduction zones are likely to undergo extensive dehydration at relatively shallow levels $(50-80 \mathrm{~km}$; Liu et al., 1996; Schmidt and Poli, 1998), and hence contain very low $\mathrm{H}_{2} \mathrm{O}$ contents once subducted to sub-arc depths (90-150 km; Tatsumi and Eggins, 1995). Evidently, a comprehensive understanding of the processes of fluid release and trace element transfer from subducted oceanic crust to the mantle wedge remain contentious.

High-pressure $(P)$, low-temperature $(T)$ blueschist to eclogite-facies terranes are widely regarded to represent exhumed fragments of subducted slabs. Therefore, studies of these terranes may reveal important information on processes operating at depth in subduction zones. Many studies based on natural samples confirm that large volumes of water are lost for subducting crust during metamorphism up to eclogite-facies (e.g., Bebout, 1995; Schmidt and Poli, 1998; Spandler et al., 2003), but petrological, isotopic and fluid inclusion evidence indicates that fluid flow in eclogite-facies rocks is highly restricted (Philippot and Selverstone, 1991; Selverstone et al., 1992; Philippot, 1993; Nadeau et al., 1993; Barnicoat and Cartwright, 1995; Miller et al., 2001). Moreover, the channelways for fluid escape from the slab are yet to be recognised (Scambelluri and Philippot, 2001).

Vein systems in eclogite-facies rocks represent products of fluid-rock interaction and therefore may provide vital information on fluid processes in subduction zones. In particular, vein systems may be used to determine fluid migration paths within the slab, element solubilities in high- $P$ fluids and the behaviour of slab rocks during fluid-induced alteration and deformation. Veins from a range of high- $P$ terranes have previously been interpreted to represent: (1) metamorphosed veins originally formed on the seafloor prior to subduction (Widmer et al., 2000); (2) direct and complete precipitates of eclogite-facies fluids (Becker et al., 1999; Gao and Klemd, 2001); (3) products of hydrous mineral breakdown (Castelli et al., 1998); (4) precipitates formed by small-scale, closed-system fluid circulation or diffusion (Nadeau et al., 1993; Philippot, 1993; Widmer and Thompson, 2001; Rubatto and Hermann, 2003) or; (5) products of metasomatic interactions between host rock and locally and externally derived fluids (Franz et al., 2001; Molina et al., 2004).

High- $P$ veins and associated metasomatic selvages hosted in eclogite have recently been discovered in the blueschist-eclogite-facies belt of northern New Caledonia. In this work, we outline the petrology, bulk rock and mineral geochemistry, and bulk oxygen isotope characteristics of these veins. Using these data, a formation history for the veins is established, which largely involves prolonged circulation of locally sourced fluid. The processes leading to the formation of these veins provide important constraints on the flow of fluids in deeply subducted oceanic crust and provide an alternative mechanism for transporting $\mathrm{H}_{2} \mathrm{O}$ to deep level in subduction zones.

\section{Analytical techniques}

\subsection{Mineral chemistry}

Major element concentrations of minerals were determined on polished thin sections using an energydispersive spectrometer equipped, JEOL 6400 scanning electron microscope housed at the Electron Microscope Unit, Australian National University (ANU). Accelerating voltage, beam current and counting time were set at $15 \mathrm{kV}, 1 \mathrm{nA}$ and $100 \mathrm{~s}$, respectively. Element concentrations were standardized against known mineral standards produced by Astimex Scientific Limited. Additional major element spot analysis and X-ray element maps of garnet grains were conducted by wavelength-dispersive spectrometry on a Cameca SX 100 electron microprobe at the Research School of Earth Sciences (RSES), ANU. For the quantitative spot analyses, acceleration voltage and beam current were set to $15 \mathrm{kV}$ and $20 \mathrm{nA}$ respectively and counting times were $20 \mathrm{~s}$ on the peak and $20 \mathrm{~s}$ on the background for each element. Qualitative major element maps were obtained using a focussed $100 \mathrm{nA}$ beam set to $25 \mathrm{kV}$ acceleration voltage. Mapping was conducted by stage scanning with a step width of $4 \mu \mathrm{m}$. Dwell time at each step was 70-100 ms. Quantification of X-ray intensities was conducted by extrapolation of multiple spot analysis of various garnet zones over the entire map region.

The trace element composition of minerals was acquired in situ by laser ablation, inductively coupled plasma mass spectrometry (LA ICP-MS) at the RSES, ANU. The LA ICP-MS employs an $\operatorname{ArF}(193 \mathrm{~nm})$ EXCIMER laser and a Hewlett Packard Agilent 7500 ICP-MS. For all analyses, laser energy, repetition rate and the spot size were set to $70 \mathrm{~mJ}, 5 \mathrm{~Hz}$ and $70 \mu \mathrm{m}$, respectively. Counting times were $20 \mathrm{~s}$ for the background and $50 \mathrm{~s}$ for sample analysis. Instrument calibration was against NIST 612 glass using the reference values of Pearce et al. (1997) for $\mathrm{Li}$, As and 
Sn, and Spandler et al. (2003) for all other elements. The internal standard isotope used to quantify the analyses was ${ }^{43} \mathrm{Ca}$ for omphacite and ${ }^{27} \mathrm{Al}$ for phengite and garnet. Mineral grains were chosen to avoid mineral inclusions during analysis. However, interference from inclusions was detected in some analyses and in most cases these interferences were manually removed during inspection of the timeresolved spectra or could be avoided during data reduction procedures.

\subsection{Bulk-rock chemistry}

Powdered whole-rock samples fused with Li borate flux were analysed for major elements using a PW 2400 wavelength-dispersive X-ray fluorescence (XRF) spectrometer housed at the Department of Earth and Marine Sciences, ANU. All trace element concentrations except $\mathrm{Li}$ were determined on $\mathrm{Li}$-borate fused discs (flux/sample ratio $=3: 1$ ) by LA ICP-MS at the RSES, ANU. Li concentrations were determined by LA ICP-MS from rock powders that were fused to glass on molybdenum strips heated in an argon atmosphere. Details of this technique are outlined in Spandler et al. (2004a). For analyses of both the Liborate and Mo strip glasses, a spot size of $100 \mu \mathrm{m}$ was used and the counting time was $30 \mathrm{~s}$ for the background and $70 \mathrm{~s}$ for sample analysis. Instrument calibration was against NIST 612 glass using the reference values of Pearce et al. (1997) for Be, Li, $\mathrm{Cu}, \mathrm{Zn}, \mathrm{Ge}, \mathrm{As}, \mathrm{Sn}$ and Sb, and Spandler et al. (2003) for all other elements. ${ }^{43} \mathrm{Ca}$ was employed as the internal standard isotope, based on $\mathrm{CaO}$ concentrations previously measured by XRF. Loss-on-ignition (LOI) values were calculated from the mass difference to $2 \mathrm{~g}$ of powdered sample after heating to $1010{ }^{\circ} \mathrm{C}$ for $1 \mathrm{~h}$.

\subsection{Stable isotope analysis}

Bulk-rock oxygen isotope analyses were performed by Kevin Faure at the Institute of Geological and Nuclear Sciences, Lower Hutt, New Zealand. Oxygen isotopes where measured using the conventional $\mathrm{BrF}_{5}$, Ni-rod method (Clayton and Mayeda, 1963). Samples where crushed to fine powder using an agate mortar and pestle. Prior to extraction of oxygen at $550{ }^{\circ} \mathrm{C}$, the samples were outgassed under vacuum at $200{ }^{\circ} \mathrm{C}$ for at least $4 \mathrm{~h}$ and pretreated with $\mathrm{BrF}_{5}$ at room temperature for $15 \mathrm{~min}$. All sample results were normalized to the quartz standard NBS-28 using a value of $+9.6 \%$. Analytical uncertainty is $\pm 0.1 \%$.

\section{Geology of the high-P belt of New Caledonia}

The north-eastern portion of New Caledonia consists of an extensive $\left(\sim 2200 \mathrm{~km}^{2}\right)$ high- $P$, low- $T$ metamorphic belt (Fig. 1A), which is interpreted to have formed during Eocene subduction of oceanic crust, causing recrystallization of sedimentary and igneous protoliths under blueschist and eclogite-facies conditions (Aitchison et al., 1995; Spandler et al., 2005). Blueschistfacies rocks in the south and west of the belt represent a thick sequence of metamorphosed sedimentary rocks with minor intercalated basaltic to rhyolitic dykes and flows (Black, 1974). The eclogite-facies rocks of the Pam Peninsula (north-eastern New Caledonia) are dominated by mafic rocks but include pelitic and ultramafic rocks all associated as melange (Maurizot et al., 1989). Recent petrologic work has shown that many of the blueschist and eclogite-facies rocks underwent similar prograde metamorphic conditions prior to peak metamorphism (Fitzherbert et al., 2003). Previously, the blueschist and eclogite-facies rocks were classified as separate tectonostratigraphic terranes respectively known as the Diahot and Pouébo Terranes (Clarke et al., 1997; Carson et al., 1999, 2000). However, Rawling and Lister (2002) suggest that the distinction of the two terranes is inappropriate, so here

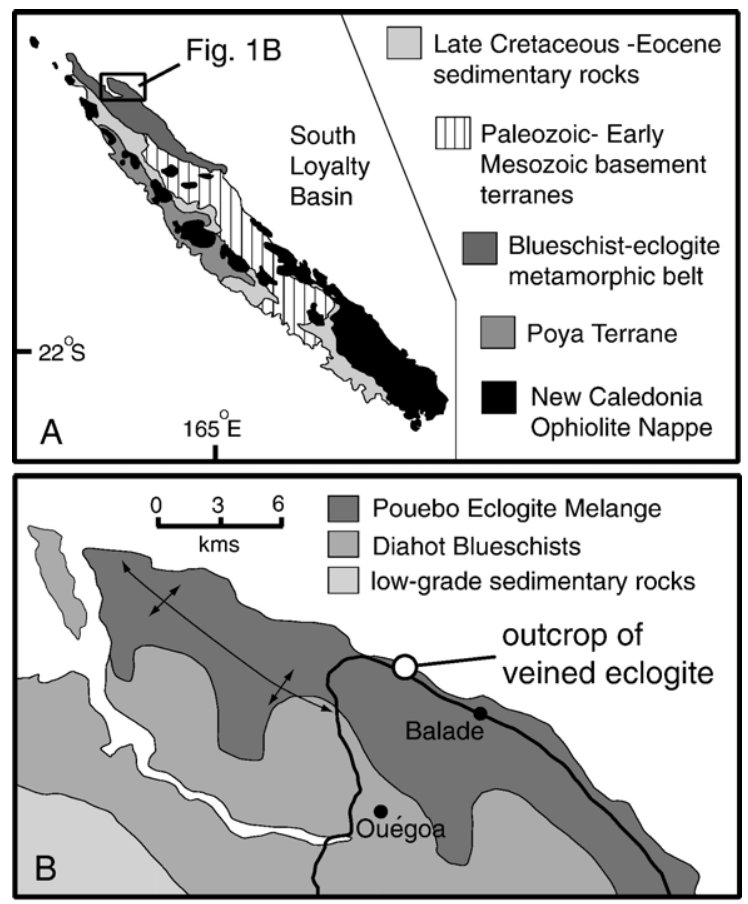

Fig. 1. (A) Major geological units of New Caledonia (after Aitchison et al., 1995). (B) Simplified geological map of the Pam Peninsula, northern New Caledonia, with location of the veined outcrop. 
the blueschist facies rocks are labelled the Diahot Blueschists and the eclogite-facies rocks of the Pam Peninsula are labelled the Pouébo Eclogite Melange (PEM).

Mafic rocks of the PEM include garnet amphibolites and eclogites and these have been used to constrain peak metamorphic condition to $1.9 \mathrm{GPa}$ and approximately $600{ }^{\circ} \mathrm{C}$ (Carson et al., 1999). The protoliths of these rocks were basalts and gabbros formed in a back-arc basin during the late Cretaceous to Paleocene (Spandler et al., 2004a, 2005). There is substantial petrographic (Spandler et al., 2004b) and geochemical (Spandler et al., 2004a) evidence that many of these mafic rocks were subject to hydrothermal alteration on the seafloor prior to subduction. During subduction, the rocks underwent progressively higher grades of metamorphism from greenschist facies metamorphism during the earliest stages of burial, followed by blueschist facies metamorphism and finally to eclogite-facies metamorphism at 44 Ma (Clarke et al., 1997; Spandler et al., 2005). Although garnet growth in the mafic rocks began at 0.7 $1.0 \mathrm{GPa}, 400-450^{\circ} \mathrm{C}$, transformation from blueschist to eclogite occurred at a higher $P-T$ range from $1.0 \mathrm{GPa}$ at $500{ }^{\circ} \mathrm{C}$ to $1.7 \mathrm{GPa}$ at $550{ }^{\circ} \mathrm{C}$ (Yokoyama et al., 1986; Clarke et al., 1997; Fitzherbert et al., 2003). The mafic rocks are expected to have released around $3 \mathrm{wt} . \%$ as

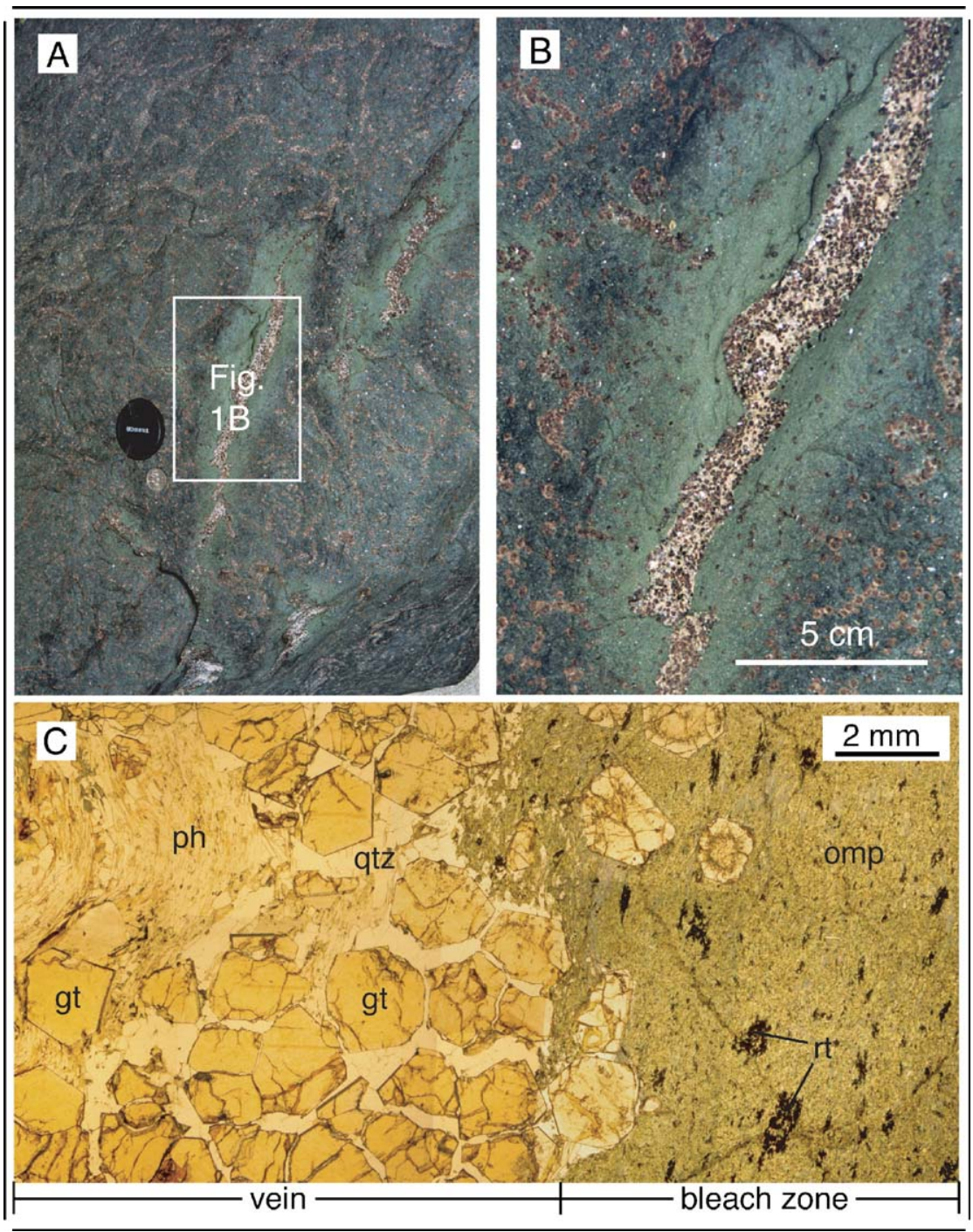

Fig. 2. (A) Outcrop photo of the mafic eclogite host rock. (B) Outcrop photo of a garnet-quartz-phengite vein with associated green bleach zone in the host rock. (C) Thin-section photomicrograph collage of a garnet-quartz-phengite vein and associated green bleach zone. Note the grain-size difference between the vein and bleach zone and lack of inclusions in minerals in the vein. 
Table 1

Petrological and mineralogical characteristics of the host rock, bleach zones, and veins

\begin{tabular}{|c|c|c|c|c|c|}
\hline Rock type & Grain size & High- $P$ mineralogy & $\begin{array}{l}\text { Retrograde } \\
\text { mineralogy }\end{array}$ & Rock origin & $\begin{array}{l}\text { gt-omp metamorphic } \\
\text { temperature }\end{array}$ \\
\hline Host rock & Medium & $\begin{array}{l}\text { gt [22], omp [15], hbl [45], rt [3], } \\
\text { qtz [5], ep [5], ph [tr], ap [tr], zr [tr] }\end{array}$ & $\begin{array}{l}\text { chl [tr], gl [1], } \\
\text { tht }[\mathrm{tr}]\end{array}$ & $\begin{array}{l}\text { Metamorphosed altered } \\
\text { MORB }\end{array}$ & $\begin{array}{l}\text { Peak } 570-610^{\circ} \mathrm{C} \text {; inclusions in } \\
\text { gt } 490-540^{\circ} \mathrm{C}\end{array}$ \\
\hline Bleach zone & Fine & $\begin{array}{l}\text { omp [60], hbl [10], gl [15], gt [7], } \\
\text { rt [3], ep [3], qtz [tr], zr [tr], py [tr] }\end{array}$ & $\begin{array}{l}\mathrm{chl}[\mathrm{tr}], \mathrm{gl}[\mathrm{tr}] \\
\text { tht }[\mathrm{tr}]\end{array}$ & $\begin{array}{l}\text { High-P, metasomatised } \\
\text { host rock }\end{array}$ & $\begin{array}{l}\text { Peak } 590-640{ }^{\circ} \mathrm{C} \text {; inclusions in } \\
\text { gt } 530-560^{\circ} \mathrm{C}\end{array}$ \\
\hline Vein & Coarse & $\begin{array}{l}\text { gt [60], qtz [35], ph [5], omp [tr], } \\
\mathrm{rt}[\operatorname{tr}], \mathrm{gl}[\operatorname{tr}], \mathrm{hbl}[\operatorname{tr}], \mathrm{ap}[\operatorname{tr}]\end{array}$ & & $\begin{array}{l}\text { Precipitate from } \\
\text { high-P fluid }\end{array}$ & $\begin{array}{l}\text { Outer gt rim } 550-590{ }^{\circ} \mathrm{C} \text {; inner } \\
\text { gt rim } 510-560^{\circ} \mathrm{C}\end{array}$ \\
\hline
\end{tabular}

Peak metamorphic temperatures calculated using coexisting compositions of omphacite and garnet and thermometer of Ravna (2000). Numbers in

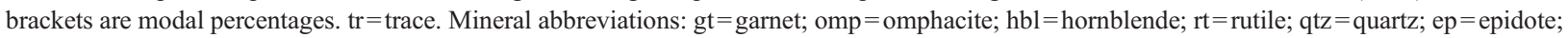
$\mathrm{ph}=$ phengite $\mathrm{ap}=$ apatite $\mathrm{zr}=\mathrm{zircon} ; \mathrm{gl}=$ glaucophane; $\mathrm{py}=$ pyrite $\mathrm{chl}=\mathrm{chlorite} ; \mathrm{tnt}=$ titanite .

$\mathrm{H}_{2} \mathrm{O}$ during the transition from blueschist to eclogitefacies (Spandler et al., 2003). Following peak metamorphism the rocks were subject to partial retrogression during uplift under high- $T$ blueschist-facies and greenschist-facies conditions (Carson et al., 2000). Nonetheless, most rocks preserve eclogite-facies mineral assemblages.

The PEM is well exposed in outcrops along the coastline of the Pam Peninsula. At a beach location approximately $2.5 \mathrm{~km}$ east of the mouth of Amoss Creek (Fig. 1B; latitude $20^{\circ} 17^{\prime} 18^{\prime \prime} \mathrm{S}$, longitude $164^{\circ} 26^{\prime} 39^{\prime \prime} \mathrm{E}$ ), there are metre-scale outcrops of mafic eclogite that contain outstanding vein arrays (Fig. 2A). The dimensions of the mafic unit and its relations with surrounding rocks are poorly constrained due to the discontinuous nature of the outcrops. However, within $10 \mathrm{~m}$ of the mafic rocks are outcrops of felsic gneisses and pelitic schists. The veins consist of coarse garnet, quartz and phengite and are invariably surrounded by bright green metasomatic selvages that separate the veins from the unaltered host rock (Fig. 2B). The petrology and mineralogy of the unaltered host rock, the veins and their enveloping green metasomatic selvages (herein labelled the bleach zones) are outlined in detail below and in Table 1.

\section{Petrography and mineralogy}

\subsection{Host rock}

The mafic rock hosting the veins is a weakly foliated amphibole eclogite that preserves the peak metamorphic mineral assemblage. Throughout the rock are thin stringers (10 mm to $0.5 \mathrm{~m}$ in length) of garnet that generally are randomly orientated, but occasionally are aligned parallel to the rock foliation. The rock mostly comprises coarse porphyroblastic garnet (up to $5 \mathrm{~mm}$ ) and tabular omphacite (up to $1 \mathrm{~mm}$ ) set in a fine-grained $(\sim 200 \mu \mathrm{m})$ matrix of barroisitic hornblende, epidote and glaucophane. Textural relations indicate that the omphacite overprints the matrix minerals, consistent with prograde transformation from blueschist to eclogite-facies. Rutile occurs in clusters throughout the rock and only has thin, poorly developed rims of retrograde titanite. Quartz, phengite and chlorite are almost exclusively found in pressure shadow zones around garnet, as has been observed in other eclogite-facies mafic rocks from New Caledonia (e.g., Carson et al., 1999; Spandler et al., 2004a). The chlorite replaces garnet and was clearly formed during minor retrogression, whereas the phengite is in textural equilibrium with garnet and is regarded as part of the peak metamorphic mineral assemblage. Tiny disseminated grains of zircon and apatite are the only other accessory minerals. Garnet cores contain a fine-grained inclusion assemblage of epidote, quartz, ilmenite and rutile, whereas the rim zones contain relatively coarse inclusions of quartz, rutile, omphacite and hornblende.

\subsection{Bleach zones}

The metasomatic bleach zones around the veins may be up to $5 \mathrm{~cm}$ thick, but in general are around 1.5 times as thick as the adjacent vein. These zones are easily distinguished from the host rock by their bright green colour, fine-grain size, low garnet content and foliation that parallels the trend of the veins. The dominant phase in the bleach zones is fine-grained $(10-50 \mu \mathrm{m})$ omphacite, which occurs with barroisitic hornblende, glaucophane, epidote, and trace zircon and pyrite. In some cases relatively coarse $(\sim 200 \mu \mathrm{m})$ glaucophane grains are present. Rutile occurs in clusters similar to those in the host rock, but rutile grains appear to be strongly corroded. Relatively rare garnet porphyroblasts have cores containing abundant inclusions of quartz, rutile, omphacite and hornblende that are enclosed by an inclusion-poor rim. Only rutile occurs as inclusions throughout the garnet grains. Phengite is absent from the 
bleach zones and quartz is only rarely found in pressure shadows around garnet. Retrogression is limited to minor chlorite replacement of garnet, glaucophane rimming hornblende, and thin titanite mantling of rutile.

\subsection{Veins}

The veins have sheet-like forms and may be up to $5 \mathrm{~cm}$ in thickness and up to several metres in length. They are invariably enveloped by metasomatic bleach zones (Fig. 2B) and often trend at a slight angle to the foliation plane. The veins largely consist of coarse (1$5 \mathrm{~mm}$ ) garnet porphyroblasts surrounded by coarse quartz and phengite. Almost all of the garnets are completely inclusion free. Only the rims of garnet grains that are directly on the margins of the vein contain inclusions of omphacite and hornblende (Fig. 2C). Interstitial quartz grains are granoblastic, while the phengite grains form foliated clusters that wrap between garnet and quartz grains. Rare grains of coarse $(\sim 500 \mu \mathrm{m})$ omphacite, epidote, amphibole, apatite, and centimetre-long rutile are also present in the vein. As these mineral grains are significantly coarser than equivalent minerals in the bleach zones, they are interpreted to have precipitated in situ in the veins rather than being transported from the bleach zones. Thin (1-2 mm) discontinuous segregations of glaucophane often occur along the margins of the veins and may continue into the bleach horizons. These segregations are most likely to be retrograde in origin. Nonetheless, within the veins there is no evidence of retrograde recrystallization.

\section{Mineral chemistry}

\subsection{Major elements}

The composition of minerals from the host rock, bleach zones and veins are similar to equivalent mineral compositions from other mafic rocks of the PEM (Clarke et al., 1997; Spandler et al., 2003). Omphacite from all three lithologies is indistinguishable in major element composition and has $0.50-0.55 \mathrm{Na}$ atoms performula-unit (Table 2). Phengite in the veins and host

Table 2

Representative EDS analyses of omphacite, amphiboles, and phengite from the host rock, bleach zones, and veins

\begin{tabular}{|c|c|c|c|c|c|c|c|c|c|c|}
\hline \multirow{2}{*}{$\frac{\text { Rock type }}{\text { Mineral }}$} & \multicolumn{5}{|l|}{ Host rock } & \multicolumn{2}{|l|}{ Bleach zone } & \multicolumn{3}{|l|}{ Vein } \\
\hline & Omphacite & Omphacite & Barroisite & Glaucophane & Phengite & Omphacite & Glaucophane & Omphacite & Hornblende & Phengite \\
\hline Location & Matrix & gt inclusion & Matrix & Matrix & Matrix & Matrix & Matrix & Matrix & Matrix & Matrix \\
\hline $\mathrm{SiO}_{2}$ & 54.87 & 54.39 & 53.81 & 56.53 & 50.28 & 55.3 & 57.23 & 55.54 & 50.45 & 50.15 \\
\hline $\mathrm{TiO}_{2}$ & 0.12 & bdl & bdl & bdl & 0.5 & 0.27 & 0.42 & bdl & 0.15 & 0.67 \\
\hline $\mathrm{Al}_{2} \mathrm{O}_{3}$ & 7.82 & 7.43 & 10.01 & 10.93 & 27.51 & 8.77 & 10.68 & 8.9 & 9.52 & 26.89 \\
\hline $\mathrm{Fe}_{2} \mathrm{O}_{3}$ & 4.97 & 6.5 & 3.37 & 2.47 & - & 6.02 & 1.87 & 4.83 & 4.36 & - \\
\hline $\mathrm{FeO}$ & 6.27 & 4.68 & 10.41 & 9.70 & 2.86 & 4.78 & 8.65 & 4.55 & 12.42 & 2.96 \\
\hline $\mathrm{MgO}$ & 6.82 & 7.06 & 10.39 & 9.59 & 3.17 & 6.18 & 10.77 & 6.94 & 9.91 & 3.46 \\
\hline $\mathrm{CaO}$ & 12.31 & 13.28 & 4.52 & 1.39 & bdl & 11.54 & 1.78 & 11.87 & 6.99 & bdl \\
\hline $\mathrm{Na}_{2} \mathrm{O}$ & 6.8 & 6.65 & 5.3 & 6.88 & 0.88 & 7.68 & 6.7 & 7.41 & 4.29 & 0.78 \\
\hline $\mathrm{K}_{2} \mathrm{O}$ & - & - & bdl & bdl & 10.12 & - & bdl & - & bdl & 10.1 \\
\hline $\mathrm{H}_{2} \mathrm{O}$ & & & 2.11 & 2.15 & 4.48 & & 2.18 & & 2.06 & 4.47 \\
\hline Sum & 99.98 & 99.99 & 99.92 & 99.64 & 99.80 & 100.54 & 100.28 & 100.16 & 100.15 & 99.48 \\
\hline \multicolumn{11}{|c|}{ Molecular formula } \\
\hline $\mathrm{O}$ & 6 & 6 & 23 & 23 & 11 & 6 & 23 & 6 & 23 & 11 \\
\hline $\mathrm{Si}$ & 2.00 & 1.98 & 7.58 & 7.85 & 3.37 & 1.99 & 7.85 & 2.00 & 7.26 & 3.37 \\
\hline $\mathrm{Ti}$ & 0.00 & 0.00 & - & - & 0.03 & 0.01 & 0.04 & 0.00 & 0.02 & 0.03 \\
\hline $\mathrm{Al}$ & 0.34 & 0.32 & 1.66 & 1.79 & 2.17 & 0.37 & 1.73 & 0.38 & 1.62 & 2.13 \\
\hline $\mathrm{Fe}^{3+}$ & 0.14 & 0.18 & 0.36 & 0.26 & & 0.16 & 0.19 & 0.13 & 0.47 & \\
\hline $\mathrm{Fe}^{2+}$ & 0.19 & 0.14 & 1.23 & 1.13 & 0.16 & 0.14 & 0.99 & 0.14 & 1.50 & 0.17 \\
\hline $\mathrm{Mg}$ & 0.37 & 0.38 & 2.18 & 1.98 & 0.31 & 0.33 & 2.20 & 0.37 & 2.13 & 0.35 \\
\hline $\mathrm{Ca}$ & 0.48 & 0.52 & 0.68 & 0.21 & - & 0.45 & 0.26 & 0.46 & 1.08 & - \\
\hline $\mathrm{Na}$ & 0.48 & 0.47 & 1.45 & 1.85 & 0.12 & 0.54 & 1.78 & 0.52 & 1.20 & 0.10 \\
\hline $\mathrm{K}$ & - & - & 0.02 & - & 0.87 & & - & & - & 0.87 \\
\hline Cation sum & 4.00 & 3.99 & 15.16 & 15.07 & 7.03 & 4.00 & 15.04 & 4.00 & 15.28 & 7.03 \\
\hline
\end{tabular}

The molecular formula for the amphiboles was calculating assuming $\Sigma$ (cations $-\mathrm{Na}-\mathrm{Ca}-\mathrm{K}$ ) $=13 . \mathrm{Fe}^{2+}$ and $\mathrm{Fe}^{3+}$ for amphiboles and omphacite were calculated based on charge balance. All Fe was assumed to be $\mathrm{Fe}^{2+}$ for phengite. $\mathrm{H}_{2} \mathrm{O}$ was calculated assuming stoichiometric mineral compositions. $\mathrm{bdl}=$ below detection limit. $\mathrm{MnO}$ was below detection in all cases. 
rock is also similar in composition with 3.3-3.4 $\mathrm{Si}$ atoms per-formula-unit, and around $10 \%$ paragonite component. Calcic amphibole is barroisitic in all samples, although barroisite in the host rock has slightly higher $\mathrm{Na} /(\mathrm{Na}+\mathrm{Ca})$ than in the bleach zones or veins (Table 2).
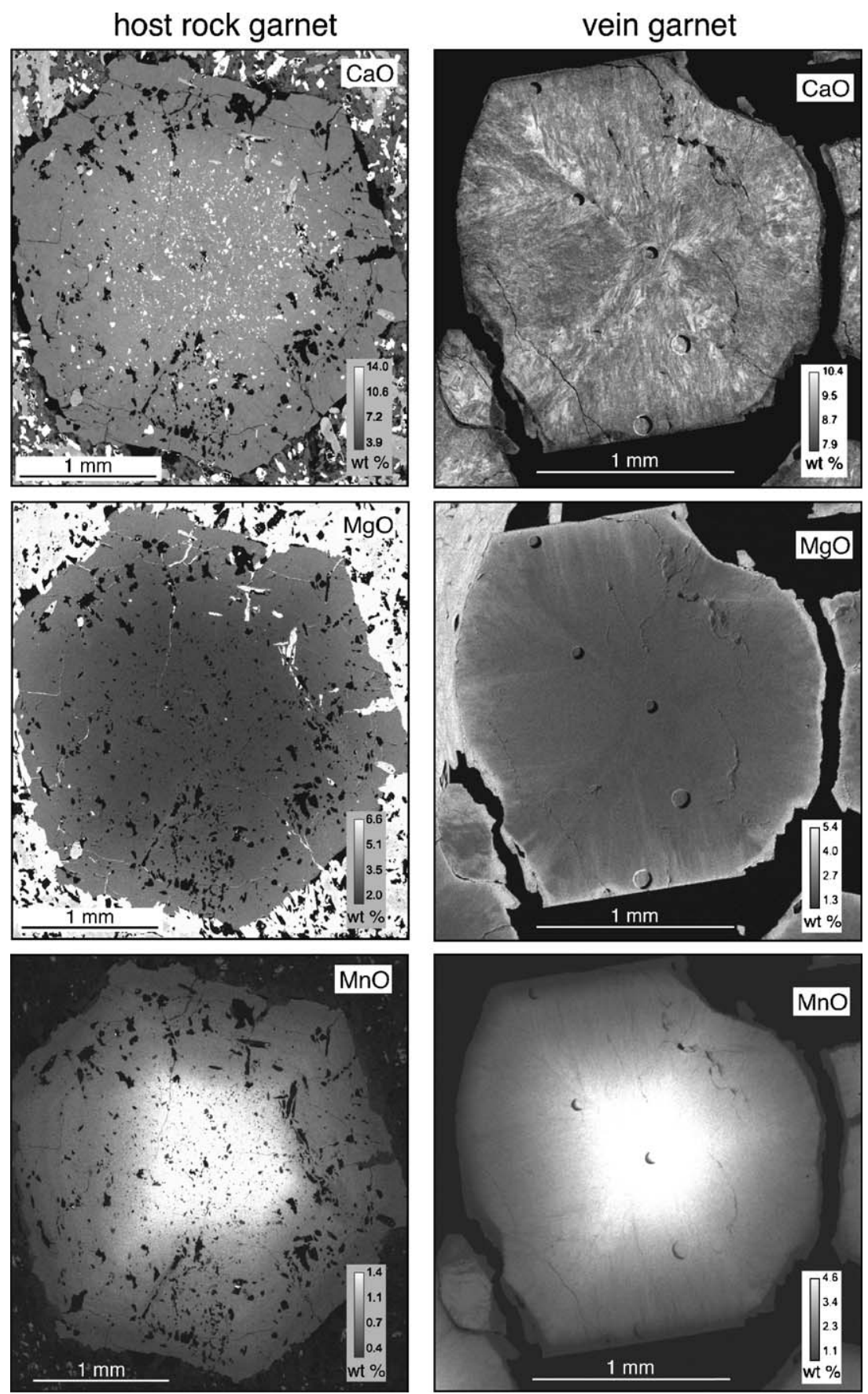

Fig. 3. Ca, Mg and Mn X-ray maps of host rock and vein garnets. The brightness and contrast of the maps have been adjusted to highlight compositional features of the garnet grains. The host rock garnets have regular core-to-rim elemental zoning and contain abundant mineral inclusions. The vein garnets are inclusion free and have complex zoning features including sector zoning, fine-scale intergrowths of Ca-rich and Ca-poor domains, and regular core-to-rim Mn zoning. The vein garnet also has a thin discontinuous outer rim that is relatively $\mathrm{Mg}$-rich and $\mathrm{Mn}$ - and Ca-poor. The circular features in the vein garnet are LA ICP-MS pits. 
Garnet grains from the host rock have welldefined continuous major-element zoning profiles (Fig. 3). Overall the garnet is almandine-rich, although there is a gradational change from relatively spessartine-rich, grossular-rich, and pyrope-poor core zones out to rim zones that are relatively spessartine and grossular depleted, but pyrope-rich. The chemical zoning correlates well with the change in inclusion mineral assemblage from the core to rim (Fig. 3). Almandine contents do not vary systematically with zoning.

In general the vein garnet is similar in composition to the host rock garnet, but the vein garnet contains no inclusions and has markedly different zoning features (Fig. 3). Major element maps reveal prominent sector zoning in the vein garnet with diffuse growth banding projecting into the crystals at right angles to grain boundaries. Calcium contents vary extensively (several wt.\%) over distances of less than $10 \mu \mathrm{m}$, producing a remarkably complex intergrowth of high and low $\mathrm{Ca}$ garnet throughout the bulk of the garnet grains. The regular core-to-rim grossular and pyrope zoning of the host rock garnet is absent from the vein garnet. However, the vein and host rock garnets have similar spessartine zoning profiles, although the vein garnet has higher Mn contents. The vein garnet also has a thin $(<100 \mu \mathrm{m})$ but distinct outer rim zone that crosscuts the growth structures of the bulk of the garnet. This rim zone is relatively homogenous in composition and has relatively high $\mathrm{Mg}$ and low $\mathrm{Ca}, \mathrm{Ti}$ and $\mathrm{Mn}$ contents (Fig. 3 and Table 3).

Metamorphic temperatures were calculated for the host rock, bleach zones and veins using $\mathrm{Fe}^{3+}$-corrected compositions of coexisting garnet and omphacite, and the geothermometer of Ravna (2000). Using garnet rim and matrix omphacite rim compositions, peak metamorphic temperatures for the host rock and bleach zone were calculated as $572-605{ }^{\circ} \mathrm{C}$ and $587-644{ }^{\circ} \mathrm{C}$, respectively. These temperatures are comparable to peak metamorphic temperatures of the PEM (Clarke et al., 1997; Carson et al., 1999). Temperatures calculated from omphacite inclusions from the shoulder of garnet cores from the host rock and bleach zone range from 487 to $540{ }^{\circ} \mathrm{C}$ and from 527 to $562{ }^{\circ} \mathrm{C}$, respectively. These temperatures are roughly $60{ }^{\circ} \mathrm{C}$ lower than calculated peak temperatures, which is consistent with progressive garnet growth during prograde metamorphism. Temperatures calculated from the outer Mg-rich rim of the

Table 3

Representative WDS (host rock and vein) and EDS (bleach zone) analyses of garnet zones from the host rock, bleach zones, and veins

\begin{tabular}{|c|c|c|c|c|c|c|c|c|c|c|c|c|c|}
\hline \multirow{2}{*}{$\frac{\text { Rock type }}{\text { Garnet type }}$} & \multicolumn{5}{|c|}{ Host rock } & \multicolumn{2}{|c|}{ Bleach zone } & \multicolumn{6}{|l|}{ Vein } \\
\hline & Core & Core & Mid & Rim & Rim & Core & Rim & $\begin{array}{l}\text { Core, high- } \\
\mathrm{Ca}\end{array}$ & $\begin{array}{l}\text { Core, low- } \\
\mathrm{Ca}\end{array}$ & $\begin{array}{l}\text { Mid, high- } \\
\mathrm{Ca}\end{array}$ & $\begin{array}{l}\text { Mid, high- } \\
\mathrm{Ca}\end{array}$ & $\begin{array}{l}\text { Outer } \\
\text { rim }\end{array}$ & $\begin{array}{l}\text { Outer } \\
\text { rim }\end{array}$ \\
\hline $\mathrm{SiO}_{2}$ & 37.21 & 37.20 & 37.07 & 37.54 & 37.45 & 37.41 & 38.11 & 36.99 & 37.08 & 37.23 & 37.03 & 37.56 & 37.47 \\
\hline $\mathrm{TiO}_{2}$ & 0.24 & 0.36 & 0.16 & 0.06 & 0.07 & bdl & bdl & 0.24 & 0.16 & 0.15 & 0.22 & bdl & 0.04 \\
\hline $\mathrm{Al}_{2} \mathrm{O}_{3}$ & 20.69 & 21.03 & 21.11 & 21.76 & 21.23 & 21.19 & 21.52 & 20.51 & 20.66 & 20.92 & 20.34 & 21.05 & 21.36 \\
\hline $\mathrm{Fe}_{2} \mathrm{O}_{3}$ & 2.41 & 2.04 & 1.70 & 1.61 & 1.82 & 2.14 & 1.32 & 2.41 & 2.16 & 2.53 & 2.48 & 0.83 & 1.59 \\
\hline $\mathrm{FeO}$ & 27.48 & 27.50 & 28.60 & 27.35 & 28.28 & 28.01 & 27.72 & 24.76 & 26.32 & 27.46 & 25.16 & 27.50 & 27.55 \\
\hline $\mathrm{MnO}$ & 1.43 & 1.79 & 0.93 & 0.32 & 0.36 & 1.07 & 0.34 & 3.88 & 3.57 & 1.46 & 2.47 & 0.33 & 0.51 \\
\hline $\mathrm{MgO}$ & 1.87 & 2.05 & 2.25 & 4.05 & 3.77 & 2.29 & 4.02 & 1.48 & 1.7 & 2.28 & 1.58 & 4.15 & 4.07 \\
\hline $\mathrm{CaO}$ & 9.29 & 8.67 & 8.17 & 7.76 & 7.22 & 8.57 & 7.74 & 9.84 & 8.59 & 8.69 & 10.53 & 7.54 & 7.26 \\
\hline Sum & 100.62 & 100.64 & 99.99 & 100.45 & 100.20 & 100.68 & 100.77 & 100.11 & 100.24 & 100.72 & 99.81 & 98.96 & 99.85 \\
\hline \multicolumn{14}{|c|}{ Molecular formula } \\
\hline $\mathrm{Si}$ & 2.96 & 2.95 & 2.96 & 2.95 & 2.96 & 2.96 & 2.98 & 2.96 & 2.97 & 2.96 & 2.97 & 2.99 & 2.97 \\
\hline $\mathrm{Ti}$ & 0.01 & 0.02 & 0.01 & 0.00 & 0.00 & 0.01 & 0.00 & 0.01 & 0.01 & 0.01 & 0.01 & 0.00 & 0.00 \\
\hline $\mathrm{Al}$ & 1.94 & 1.97 & 1.98 & 2.02 & 1.98 & 1.98 & 1.99 & 1.93 & 1.95 & 1.95 & 1.92 & 1.97 & 1.99 \\
\hline $\mathrm{Fe}^{3+}$ & 0.16 & 0.13 & 0.11 & 0.10 & 0.11 & 0.13 & 0.08 & 0.16 & 0.13 & 0.15 & 0.15 & 0.05 & 0.10 \\
\hline $\mathrm{Fe}^{2+}$ & 1.82 & 1.83 & 1.91 & 1.79 & 1.87 & 1.85 & 1.81 & 1.65 & 1.76 & 1.82 & 1.69 & 1.83 & 1.82 \\
\hline $\mathrm{Mn}$ & 0.10 & 0.12 & 0.06 & 0.02 & 0.02 & 0.07 & 0.02 & 0.26 & 0.24 & 0.10 & 0.17 & 0.02 & 0.03 \\
\hline $\mathrm{Mg}$ & 0.22 & 0.24 & 0.27 & 0.47 & 0.45 & 0.27 & 0.47 & 0.18 & 0.2 & 0.27 & 0.19 & 0.49 & 0.48 \\
\hline $\mathrm{Ca}$ & 0.79 & 0.74 & 0.70 & 0.65 & 0.61 & 0.73 & 0.65 & 0.85 & 0.74 & 0.74 & 0.90 & 0.64 & 0.61 \\
\hline Spessartine & 0.03 & 0.04 & 0.02 & 0.01 & 0.01 & 0.02 & 0.01 & 0.09 & 0.08 & 0.03 & 0.06 & 0.01 & 0.01 \\
\hline Almandine & 0.62 & 0.62 & 0.65 & 0.61 & 0.63 & 0.63 & 0.61 & 0.56 & 0.6 & 0.62 & 0.57 & 0.61 & 0.62 \\
\hline Pyrope & 0.08 & 0.08 & 0.09 & 0.16 & 0.15 & 0.09 & 0.16 & 0.06 & 0.07 & 0.09 & 0.06 & 0.16 & 0.16 \\
\hline Grossular & 0.27 & 0.25 & 0.24 & 0.22 & 0.21 & 0.25 & 0.22 & 0.29 & 0.25 & 0.25 & 0.31 & 0.22 & 0.21 \\
\hline
\end{tabular}

$\mathrm{Fe}^{2+}$ and $\mathrm{Fe}^{3+}$ for garnet were calculated based on charge balance. bdl=below detection limit. All analyses are normalised to 12 oxygens and 8 cations. 
vein garnet are between 545 and $590{ }^{\circ} \mathrm{C}$, whereas temperatures obtained using the garnet rim zone immediately adjacent to the outer rim zone range from 506 to $564{ }^{\circ} \mathrm{C}$. The small difference in calculated temperatures $\left(\sim 30{ }^{\circ} \mathrm{C}\right)$ for the two garnet rim zones indicates that the compositional differences between these zones is not due to large differences in metamorphic conditions.

\subsection{Trace elements}

Many of the trace element analyses of minerals in the host rock and bleach zones were compromised by abundant inclusions of trace element-rich minerals such as apatite, rutile and zircon. In most cases, the effects of these inclusions on the analysis could be manually removed during examination of the time-resolved spectra prior to data reduction, but in some cases the concentration of some elements could not be determined (e.g., $\mathrm{Zr}$ in garnet; Table 4). By contrast, no inclusions were encountered during analysis of the vein minerals. Omphacite from the host rock and bleach zones have remarkably similar trace element compositions (Table 4). The omphacites have high $\mathrm{Li}$ and $\mathrm{V}$ concentrations and low contents of most other trace elements, as is characteristic of omphacites from eclogite-facies rocks (Hermann, 2002; Zack et al., 2002; Spandler et al., 2003).

Phengite is the major host for the large-ion lithophile elements (LILE; K, Cs, Rb, Ba). Phengite from the host rock is comparable to phengite compositions from other mafic rocks from the PEM (Fig. 4). Phengite is not present in the bleach zone, but phengite from the bleach zone/host-rock boundary have lower $\mathrm{Sr}, \mathrm{Cs}, \mathrm{Pb}$ and $\mathrm{Sn}$ contents than the host-rock phengite. By contrast, phengite from the veins have significantly higher $\mathrm{Li}$,

Table 4

Representative trace element analyses of garnet, omphacite, and phengite from the host rock, bleach zones, and veins

\begin{tabular}{|c|c|c|c|c|c|c|c|c|c|c|c|c|c|}
\hline \multirow{2}{*}{$\frac{\text { Rock }}{\text { Min. }}$} & \multicolumn{3}{|l|}{ Host } & \multicolumn{3}{|l|}{ Vein } & \multirow{2}{*}{$\frac{\text { Host }}{\text { omp }}$} & \multirow{2}{*}{$\frac{\text { Bleach }}{\text { omp }}$} & \multicolumn{2}{|l|}{ Host } & \multicolumn{2}{|l|}{ Vein } & \multirow{2}{*}{$\frac{\text { Bleach/Host }}{\mathrm{ph}}$} \\
\hline & gt core & gt mid & gt rim & gt core & gt mid & gt rim & & & ph & $\mathrm{ph}$ & $\mathrm{ph}$ & $\mathrm{ph}$ & \\
\hline $\mathrm{Li}$ & 2.73 & 2.26 & 1.73 & nd & 3.28 & 2.21 & 44.4 & 45.1 & 14.5 & 10.9 & 17.4 & 24.3 & 12.6 \\
\hline $\mathrm{Ti}$ & 1200 & 769 & 336 & 1020 & 960 & 682 & 447 & 380 & 1880 & 1840 & 2200 & 1940 & 1330 \\
\hline V & 139 & 176 & 107 & 123 & 155 & 106 & 772 & 654 & 568 & 568 & 525 & 518 & 313 \\
\hline $\mathrm{Cr}$ & 37.4 & 41.8 & 55.0 & 17.9 & 44.7 & 14.4 & 75.7 & 118 & 75.2 & 77.2 & 32.0 & 64.3 & 61.9 \\
\hline $\mathrm{Ni}$ & 0.51 & 0.52 & 0.38 & 0.20 & 0.46 & 0.58 & 11.4 & 19.2 & 14.1 & 14.9 & 26.3 & 20.4 & 7.83 \\
\hline $\mathrm{Cu}$ & nd & nd & nd & nd & nd & nd & nd & nd & 0.85 & 0.95 & 3.61 & 22.1 & 0.50 \\
\hline $\mathrm{Zn}$ & nd & nd & nd & nd & nd & nd & nd & nd & 62.7 & 66.6 & 68.8 & 62.1 & 55.5 \\
\hline As & 0.13 & 0.19 & 0.12 & nd & bdl & 0.13 & 0.15 & 0.11 & 0.19 & 0.10 & 0.05 & 0.25 & 0.08 \\
\hline $\mathrm{Rb}$ & 0.31 & 0.03 & 0.03 & nd & 0.03 & 0.01 & bdl & bdl & 282 & 292 & 347 & 341 & 281 \\
\hline $\mathrm{Sr}$ & 0.10 & 0.13 & 0.04 & 0.15 & 0.03 & 0.01 & 13.9 & 7.72 & 4.55 & 6.23 & 59.9 & 22.4 & 1.21 \\
\hline $\mathrm{Y}$ & 348 & 143 & 191 & 162 & 168 & 66 & 0.84 & 0.92 & 0.12 & nd & 0.22 & 0.25 & 0.29 \\
\hline $\mathrm{Zr}$ & nd & nd & nd & 2.23 & 2.41 & 3.18 & 20.1 & 11.9 & 0.06 & nd & 0.11 & 0.07 & nd \\
\hline $\mathrm{Nb}$ & 0.04 & bdl & bdl & 0.02 & bdl & bdl & bdl & bdl & 0.08 & 0.07 & 0.09 & 0.15 & 0.15 \\
\hline $\mathrm{Sn}$ & 0.17 & 0.12 & 0.06 & nd & 0.09 & 0.14 & 1.07 & 0.87 & 1.44 & 1.53 & 1.92 & 1.47 & 0.52 \\
\hline Cs & nd & nd & nd & nd & nd & nd & nd & nd & 1.81 & 1.97 & 2.99 & 2.87 & 1.08 \\
\hline $\mathrm{Ba}$ & 0.01 & 0.06 & 0.01 & 0.01 & 0.04 & bdl & 0.002 & 0.07 & 2270 & 2250 & 2300 & 2300 & 2110 \\
\hline $\mathrm{La}$ & bdl & bdl & bdl & 0.004 & bdl & bdl & bdl & 0.02 & nd & nd & nd & nd & nd \\
\hline $\mathrm{Ce}$ & 0.01 & 0.01 & 0.03 & 0.004 & bdl & bdl & bdl & 0.08 & nd & nd & nd & nd & nd \\
\hline $\mathrm{Nd}$ & bdl & bdl & 0.03 & 0.008 & bdl & 0.04 & bdl & 0.01 & nd & nd & nd & nd & nd \\
\hline $\mathrm{Sm}$ & 0.03 & 0.09 & 0.35 & 0.01 & 0.10 & 0.52 & 0.03 & 0.04 & nd & nd & nd & nd & nd \\
\hline $\mathrm{Eu}$ & 0.07 & 0.11 & 0.53 & 0.02 & 0.15 & 0.59 & 0.02 & 0.05 & nd & nd & nd & nd & nd \\
\hline $\mathrm{Gd}$ & 0.95 & 1.34 & 5.95 & 0.26 & 1.93 & 5.70 & 0.02 & 0.03 & nd & nd & nd & nd & nd \\
\hline $\mathrm{Tb}$ & 1.04 & 0.96 & 3.67 & 0.29 & 1.35 & 1.87 & 0.10 & 0.06 & nd & nd & nd & nd & nd \\
\hline Dy & 24.6 & 13.7 & 35.4 & 7.22 & 18.5 & 12.3 & 0.20 & 0.20 & nd & nd & nd & nd & nd \\
\hline Ho & 11.91 & 4.67 & 7.03 & 5.04 & 5.75 & 2.08 & 0.04 & 0.04 & nd & nd & nd & nd & nd \\
\hline $\mathrm{Er}$ & 57 & 17.8 & 15.9 & 42.3 & 18.9 & 4.68 & 0.10 & 0.06 & nd & nd & nd & nd & nd \\
\hline $\mathrm{Tm}$ & nd & nd & nd & 14.1 & 2.69 & 0.56 & nd & 0.01 & nd & nd & nd & nd & nd \\
\hline $\mathrm{Yb}$ & 87 & 21.0 & 9.43 & 182 & 17.3 & 3.25 & 0.06 & 0.09 & nd & nd & nd & nd & nd \\
\hline $\mathrm{Lu}$ & 11.06 & 3.32 & 1.22 & 37.6 & 2.50 & 0.45 & 0.01 & 0.01 & nd & nd & nd & nd & nd \\
\hline Hf & nd & nd & nd & 0.04 & 0.09 & 0.07 & 0.7 & 0.45 & 0.07 & nd & 0.04 & 0.05 & nd \\
\hline $\mathrm{Ta}$ & 0.05 & 0.01 & 0.03 & 0.02 & 0.02 & bdl & bdl & bdl & 0.16 & 0.15 & 0.13 & 0.14 & 0.14 \\
\hline $\mathrm{Pb}$ & bdl & bdl & bdl & bdl & 0.01 & bdl & 0.06 & 0.08 & 0.38 & 0.48 & 1.69 & 2.96 & 0.10 \\
\hline
\end{tabular}

Mineral abbreviations as in Table 1 . bdl= below detection limit, $\mathrm{nd}=$ no data. 


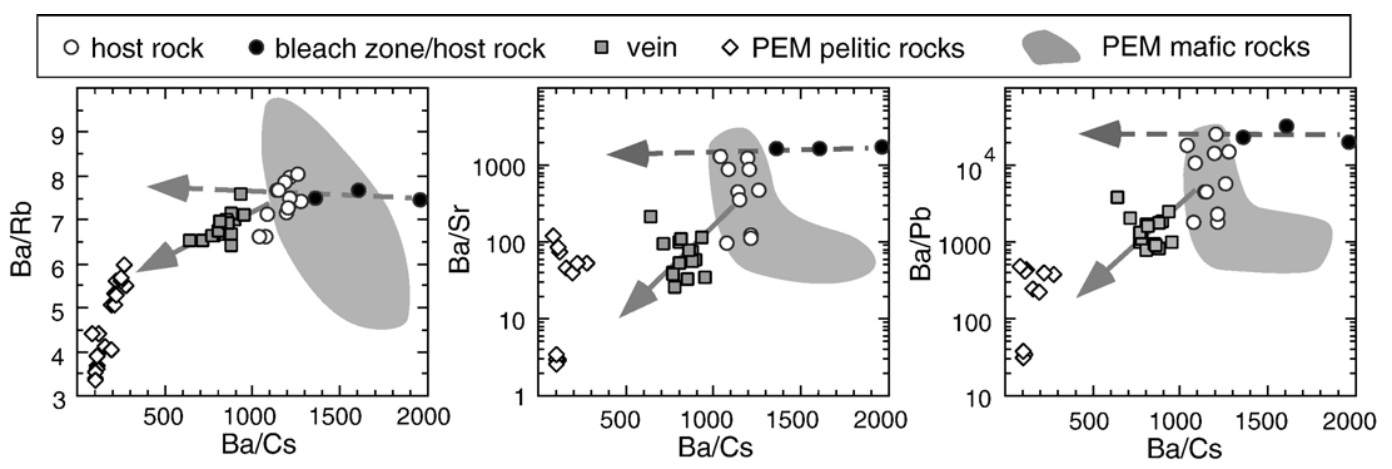

Fig. 4. Trace element ratios of phengite from the host rock, bleach zone/host-rock boundary and veins. Also shown are phengite compositions from PEM mafic and pelitic rock (from Spandler et al., 2003 and Spandler, unpublished data). The dashed grey arrow is the compositional trend expected for mass transfer of phengite components from the bleach zone to the veins. The solid grey arrow is the compositional trend expected for mixing between phengite components from the host rock and pelitic rocks.

$\mathrm{Cs}, \mathrm{Pb}, \mathrm{Sr}$ and $\mathrm{Rb}$ contents than the host-rock phengite (Fig. 4; Table 4).

The existence of fine scale zoning of trace elements in garnet could not be resolved due to the large spot size used for LA ICP MS analysis. Nonetheless, pronounced grain scale zoning of REE is apparent in garnet from both the host rock and veins (Table 4). REE patterns of garnets feature typical enrichment in M-HREE, but the cores have significantly higher HREE contents (Fig. 5). Garnet rims are relatively depleted in HREE, but have higher MREE than the cores. Zoning trends are similar in the host-rock and vein garnets, although the vein garnet cores tend have higher HREE and steeper REE patterns that the host-rock garnet cores.

\section{Bulk-rock geochemistry}

The major and trace element composition of samples of the host rock, the bleach zone and a large vein are presented in Table 5 and Fig. 6 . Representative fist-sized samples of the host rock and bleach zone were used, whereas only a relatively small amount of vein material ( $\sim 100 \mathrm{~g})$ was available for analysis, due to sampling difficulties. The host rock has a basaltic major element composition, although it has high $\mathrm{TiO}_{2}$ and $\mathrm{Fe}_{2} \mathrm{O}_{3}$ contents. Most trace element concentrations are also around 2 to 3 times higher than average MORB (Sun and McDonough, 1989) with the exception of $\mathrm{Sr}, \mathrm{Cr}$ and $\mathrm{Ni}$, which are relatively depleted. Chondrite-normalised REE patterns feature slight LREE depletion and a negative Eu anomaly. REE and high field strength element (HFSE) patterns are similar to, but intermediate between Type III and Type VII eclogite-facies mafic rocks from the PEM (Spandler et al., 2004a). These rock-types represent metamorphosed normal-MORB and $\mathrm{Fe}-\mathrm{Ti}$ basalt, respectively.

The bleach zone has similar $\mathrm{SiO}_{2}, \mathrm{Al}_{2} \mathrm{O}_{3}, \mathrm{TiO}_{2}$ and $\mathrm{MgO}$ contents to the host rock, but has significantly higher $\mathrm{CaO}, \mathrm{Na}_{2} \mathrm{O}$ and $\mathrm{SO}_{3}$, and lower $\mathrm{Fe}_{2} \mathrm{O}_{3}, \mathrm{MnO}$, $\mathrm{P}_{2} \mathrm{O}_{5}$ and $\mathrm{K}_{2} \mathrm{O}$ contents. Most trace element concentrations are similar to or slightly lower that the host rock, although $\mathrm{Li}$ and $\mathrm{V}$ contents are clearly elevated in the bleach zone, and $\mathrm{Ba}, \mathrm{Y}$ and HREE are relatively depleted (Fig. 6). Nonetheless, many of the distinctive geochemical features of the host rock, such as negative Eu and $\mathrm{Sr}$ anomalies, are also present in the bleach zone.
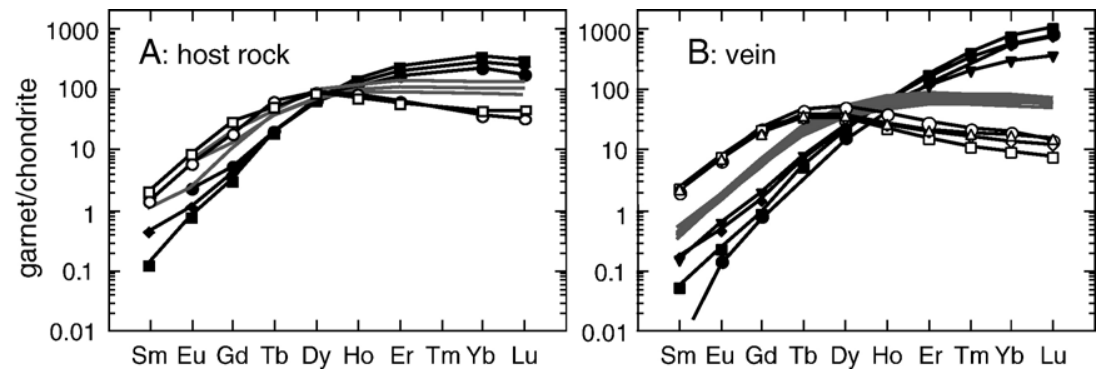

Fig. 5. Chondrite-normalised middle-heavy rare-earth element patterns for garnet from the host rock (A) and veins (B). Black lines with open symbols represent garnet rim compositions, and black lines with filled symbols represent garnet core compositions. Grey lines represent garnet mid-zone compositions. Normalising values are from Taylor and McLennan (1985). 
Table 5

Bulk-rock major-element (wt.\%), trace-element (ppm), and oxygen isotope (\%o relative to VSMOW) composition of the vein, bleach zone and host rock

\begin{tabular}{|c|c|c|c|}
\hline & Host rock & Bleach zone & Vein \\
\hline $\mathrm{SiO}_{2}$ & 50.22 & 50.82 & 55.67 \\
\hline $\mathrm{TiO}_{2}$ & 3.07 & 3.01 & 0.091 \\
\hline $\mathrm{Al}_{2} \mathrm{O}_{3}$ & 11.98 & 10.19 & 13.6 \\
\hline $\mathrm{Fe}_{2} \mathrm{O}_{3}$ & 16.81 & 12.92 & 19.65 \\
\hline $\mathrm{MnO}$ & 0.188 & 0.109 & 1.33 \\
\hline $\mathrm{MgO}$ & 7.00 & 6.21 & 1.51 \\
\hline $\mathrm{CaO}$ & 7.18 & 10.81 & 5.58 \\
\hline $\mathrm{Na}_{2} \mathrm{O}$ & 2.87 & 5.40 & 0.041 \\
\hline $\mathrm{K}_{2} \mathrm{O}$ & 0.078 & 0.048 & 0.446 \\
\hline $\mathrm{P}_{2} \mathrm{O}_{5}$ & 0.156 & 0.043 & 0.029 \\
\hline $\mathrm{SO}_{3}$ & 0.018 & 0.137 & 0.017 \\
\hline LOI & 0.58 & 0.53 & nd \\
\hline Total & 100.15 & 100.23 & 97.96 \\
\hline$\delta^{18} \mathrm{O}$ & +8.2 & +8.2 & +9.4 \\
\hline $\mathrm{Li}$ & 13.1 & 34.0 & 3.36 \\
\hline $\mathrm{Be}$ & 1.21 & 1.26 & 0.50 \\
\hline $\mathrm{P}$ & 912 & 202 & 114 \\
\hline $\mathrm{Sc}$ & 46.6 & 41.5 & 48.8 \\
\hline $\mathrm{Ti}$ & 18420 & 17330 & 729 \\
\hline $\mathrm{V}$ & 462 & 612 & 140 \\
\hline $\mathrm{Cr}$ & 66 & 66 & 30.4 \\
\hline $\mathrm{Ni}$ & 40.0 & 30.7 & 4.86 \\
\hline $\mathrm{Cu}$ & 18.5 & 15.30 & 7.15 \\
\hline $\mathrm{Zn}$ & 122 & 79 & 31.6 \\
\hline $\mathrm{Ga}$ & 17.8 & 19.4 & 12.2 \\
\hline $\mathrm{Ge}$ & 3.78 & 3.31 & 3.79 \\
\hline As & 1.67 & 1.80 & 0.31 \\
\hline $\mathrm{Rb}$ & 1.47 & 1.10 & 12.8 \\
\hline $\mathrm{Sr}$ & 50.1 & 51.9 & 4.09 \\
\hline $\mathrm{Y}$ & 67 & 33.5 & 96 \\
\hline $\mathrm{Zr}$ & 214 & 195 & 13.3 \\
\hline $\mathrm{Nb}$ & 5.09 & 5.74 & 1.13 \\
\hline $\mathrm{Sn}$ & 2.44 & 2.28 & 0.84 \\
\hline $\mathrm{Sb}$ & 0.35 & 0.31 & 0.09 \\
\hline Cs & 0.024 & 0.020 & 0.10 \\
\hline $\mathrm{Ba}$ & 15.8 & 4.08 & 105 \\
\hline $\mathrm{La}$ & 7.19 & 6.63 & 0.069 \\
\hline $\mathrm{Ce}$ & 22.0 & 19.8 & 0.048 \\
\hline $\operatorname{Pr}$ & 3.80 & 3.44 & 0.007 \\
\hline $\mathrm{Nd}$ & 20.7 & 18.6 & 0.027 \\
\hline $\mathrm{Sm}$ & 6.93 & 6.26 & 0.13 \\
\hline $\mathrm{Eu}$ & 2.21 & 1.94 & 0.14 \\
\hline $\mathrm{Gd}$ & 9.44 & 7.61 & 2.56 \\
\hline $\mathrm{Tb}$ & 1.72 & 1.19 & 0.91 \\
\hline Dy & 11.1 & 6.60 & 10.8 \\
\hline Но & 2.36 & 1.22 & 3.19 \\
\hline $\mathrm{Er}$ & 6.62 & 3.29 & 10.7 \\
\hline $\mathrm{Tm}$ & 0.93 & 0.45 & 1.60 \\
\hline $\mathrm{Yb}$ & 6.24 & 3.14 & 11.4 \\
\hline $\mathrm{Lu}$ & 0.93 & 0.50 & 1.77 \\
\hline Hf & 5.32 & 4.79 & 0.29 \\
\hline $\mathrm{Pb}$ & 3.08 & 3.09 & 2.12 \\
\hline $\mathrm{Th}$ & 0.36 & 0.32 & 0.004 \\
\hline $\mathrm{U}$ & 0.16 & 0.18 & 0.018 \\
\hline
\end{tabular}

nd $=$ no data.
The veins have relatively high $\mathrm{SiO}_{2}, \mathrm{Fe}_{2} \mathrm{O}_{3}, \mathrm{MnO}$ and $\mathrm{K}_{2} \mathrm{O}$, and low $\mathrm{TiO}_{2}, \mathrm{Na}_{2} \mathrm{O}$ and $\mathrm{P}_{2} \mathrm{O}_{5}$ contents, which directly reflects the dominant mineralogy of garnet, quartz and phengite. Trace elements in the veins are generally low except for high HREE and Y contents, and the high $\mathrm{Cs}, \mathrm{Rb}$ and $\mathrm{Ba}$ contents. These elements strongly partition into garnet and phengite respectively. Light REE contents are particularly low, as highlighted by the very steeply sloping chondrite-normalised REE pattern (Fig. 6).

\section{Bulk-rock oxygen isotopes}

Both the host rock and bleach zone have a $\delta^{18} \mathrm{O}$ value of $+8.2 \%$, whereas the vein has an oxygen isotope composition of $+9.4 \%$. To assess the effects of bulkrock compositional variation on isotopic composition, we use the chemical index of Garlick (1966) as defined below;

Garlick Index $=\frac{(\mathrm{Si}+0.58 \mathrm{Al}) \text { equivalents }}{\text { total cations equivalents }}$

Several studies have shown that there is a direct and predictable relationship between the Garlick Index and oxygen isotopic compositions of rocks and silicate minerals in isotopic equilibrium (Garlick, 1966; Schliestedt and Matthews, 1987; Ganor et al., 1994). Using the calibration of isotopic fractionation versus chemical composition of Ganor et al. (1994), we are able to assess if the host rock, bleach zones and veins were in isotopic equilibrium at eclogite-facies. We plot bulk rock oxygen isotopic composition against the Garlick Index of our samples together with the calculated isopleths of rocks in equilibrium with a $600{ }^{\circ} \mathrm{C}$ fluid of varying isotopic composition (Fig. 7). All three samples plot on or close to the $10 \%$ isopleth, indicating that the three rock-types equilibrated with a fluid of $\sim 10 \% \delta^{18} \mathrm{O}$ at peak metamorphic temperatures.

\section{Mass balance calculations}

A Gresens style mass-balance analysis is often conducted to assess mass transfer in vein selvages or metasomatic zones (Gresens, 1967). In particular, the isocon method of Grant (1986) has been widely used for assessing the degree of element mobilisation and whether the mobilised components were locally or externally derived (e.g., Widmer and Thompson, 2001; Molina et al., 2004). A requirement for the isocon method is assignment of a reference element, which remained immobile during mass transfer processes 


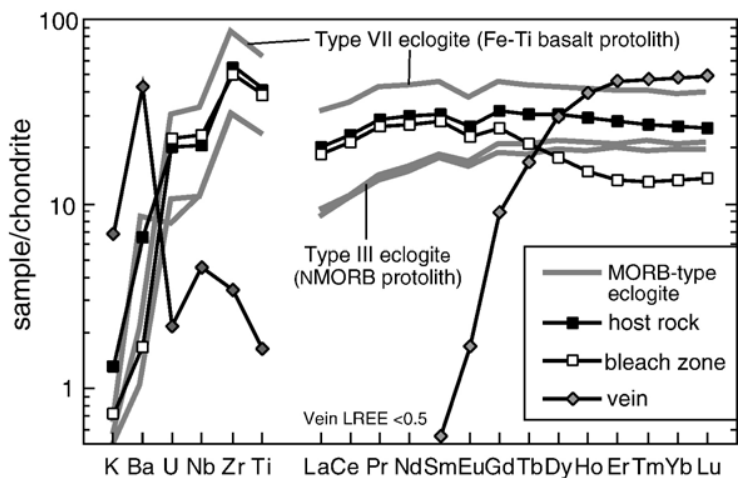

Fig. 6. Chondrite-normalised bulk-rock trace element patterns for the host rock, bleach zones, and veins. Data for the Type III and Type VII MORB-like eclogites are taken from Spandler et al. (2004a). Normalising values are from Taylor and McLennan (1985).

(Grant, 1986). It is clear that significant mass transfer was associated with formation of the bleach zones and veins, as there are significant geochemical and mineralogical differences between each of the rock types. The LREE contents of the bleach zone and host rock are similar, whereas the veins have very low LREE contents (Table 5). These features indicate that the LREE may have remained relatively immobile during vein and bleach zone formation, so we use the LREE as immobile reference elements for analysis of mass gain or loss during bleach zone formation (Fig. 8). On this basis, the isocon analysis indicate that the bleach zones have gained around $10 \%$ in mass mostly as $\mathrm{CaO}, \mathrm{Na}_{2} \mathrm{O}, \mathrm{SiO}_{2}$, $\mathrm{SO}_{3}, \mathrm{Li}$ and $\mathrm{V}$. Along with the LREE, elements that have remained immobile include $\mathrm{MgO}, \mathrm{TiO}_{2}, \mathrm{Cr}, \mathrm{Zr}, \mathrm{Sn}, \mathrm{Ge}$, $\mathrm{Th}$ and Sc, whereas significant amounts $(>20 \%)$ of $\mathrm{P}_{2} \mathrm{O}_{5}, \mathrm{MnO}, \mathrm{HREE}, \mathrm{Y}, \mathrm{K}_{2} \mathrm{O}, \mathrm{Ba}$ and $\mathrm{Zn}$ have been lost from the bleach zones.

To test if element loss from the bleach zone can account for element concentrations in the veins, we have calculated relative element enrichments in the veins by double normalising the vein composition, firstly to the host rock and then to the degree of $\mathrm{Yb}$ loss from the bleach zone. This double normalising procedure eliminates the need for calculation of rock volumes and proportions, but assumes conservation of the HREE flux from the bleach zone to the veins. This assumption is supported by contrasting REE patterns and garnet proportions of the bleach zone and veins (Fig. 9) and the highly immobile nature of the HREE (Stalder et al., 1998; Green and Adam, 2003). For many elements depleted from the bleach zone, there is a good correlation with the relative element enrichment in the veins (Fig. 9). However, there is a poor correlation for several elements; $\mathrm{P}$ is highly depleted in the veins and the bleach zones, whereas the LILE and Mn concentrations in the veins are much higher than can be accounted for by element loss from the bleach zones. These results indicate that a source external from the bleach zone is required to account for the loss of $\mathrm{P}$ and the high contents of LILE and Mn in the veins.

\section{Discussion}

\subsection{Origin and evolution of the host rock}

The chemical composition of mafic rocks from the PEM are generally unaffected by eclogite-facies metamorphism (Spandler et al., 2003, 2004a). Stable isotope studies suggest that high- $P$ rocks also preserve their pre-metamorphic isotopic composition (Barnicoat and Cartwright, 1995; Putlitz et al., 2000; Miller et al., 2001). Therefore, the pre-metamorphic origin and history of the host rock can be evaluated using the geochemical and oxygen isotopic data presented above. The major and trace element composition of the host rock is intermediate between MORB type eclogites and $\mathrm{Fe}-\mathrm{Ti}$ basalt type eclogites (Fig. 6; Spandler et al.,

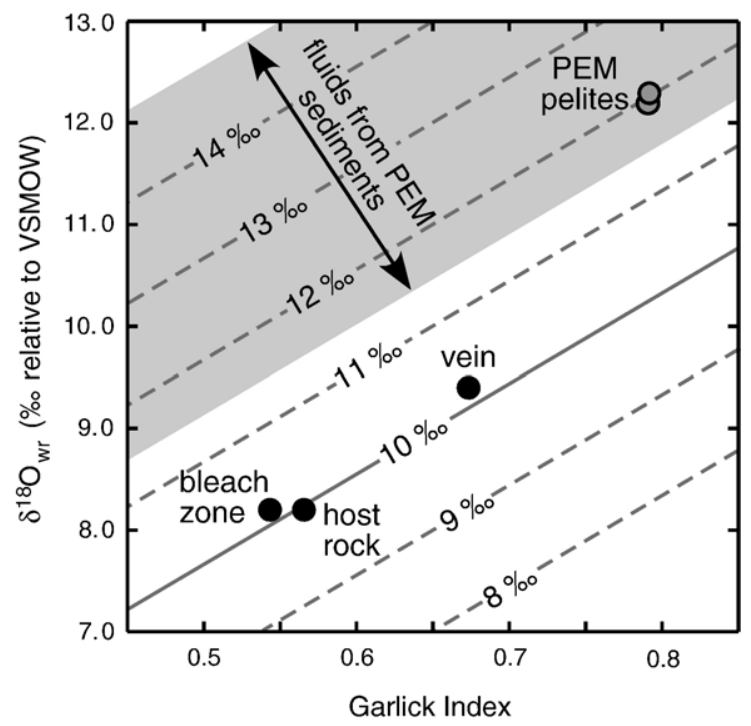

Fig. 7. Plot of bulk-rock oxygen isotope data (\%o relative to VSMOW) versus the Garlick Index for the host rock, bleach zones, veins and two pelites from the PEM (Spandler, unpublished data). See text for details on calculation of the Garlick Index. Isopleths represent isotopic compositions of fluid in equilibrium with bulk rock compositions at $600{ }^{\circ} \mathrm{C}$. Isopleths were calculated using the quartz-mineral fractionation factor versus Garlick Index calibration of Ganor et al. (1994) and the quartz-fluid fractionation factor of Zheng (1993a). The compositional range of fluids from PEM pelitic rocks was calculated from the isotopic composition of quartz and phengite presented in Black (1974) and the mineral-fluid fractionation factors of Zheng (1993a,b). 

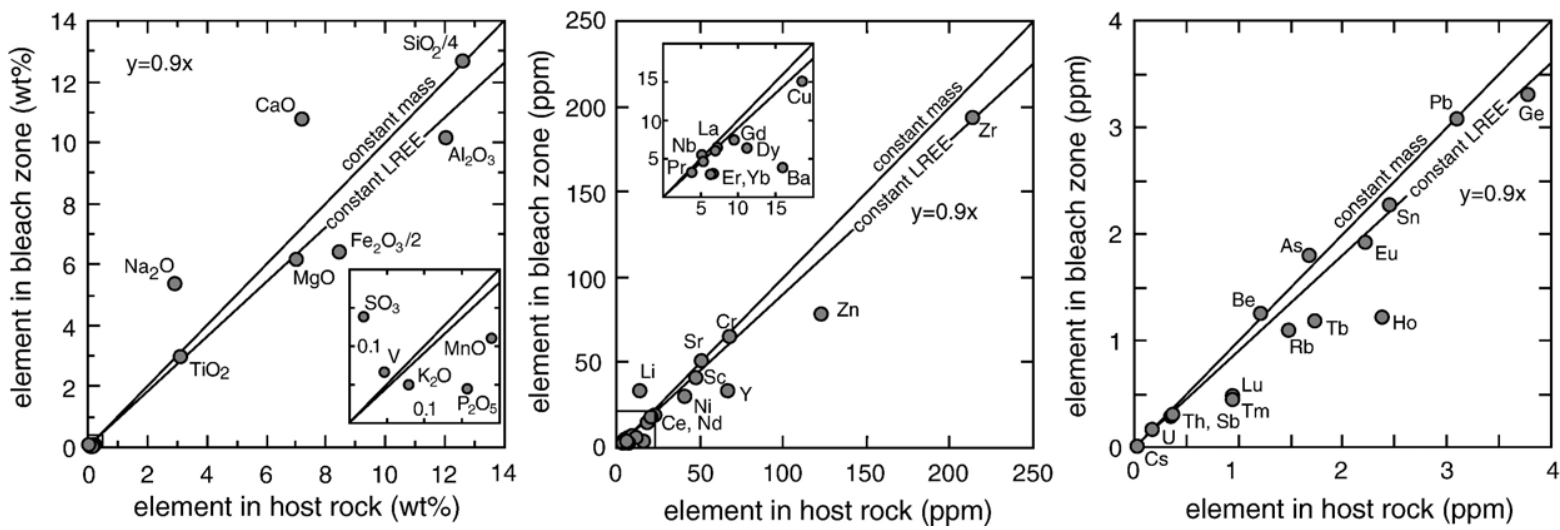

Fig. 8. Isocon diagrams of bleach zone against host rock. The line with equation $y=0.9 x$ is based on conservation of LREE in the bleach zone. These mass balance constraints require significant addition of $\mathrm{Ca}, \mathrm{Na}, \mathrm{Li}, \mathrm{S}$ and $\mathrm{V}$ to the bleach zones and loss of LILE, P, Zn, Y, Mn, and HREE.

2004a), and hence is consistent with an igneous origin as a fractionated MORB. The negative Eu anomaly and low $\mathrm{Sr}, \mathrm{Ni}$ and $\mathrm{Cr}$ contents reflect fractionation of plagioclase, olivine and spinel from the melt prior to crystallisation. The elevated $\delta^{18} \mathrm{O}$ value compared to mantle is interpreted to result from shallow-level seawater alteration of the rock after igneous formation, but prior to high- $P$ metamorphism. This is consistent with other geochemical and petrographic evidence of widespread seafloor alteration of mafic rocks of the PEM prior to subduction (Spandler et al., 2004a,b). Seafloor alteration of the host rock may also account for the relatively high $\mathrm{MgO}$ content (Humphris and

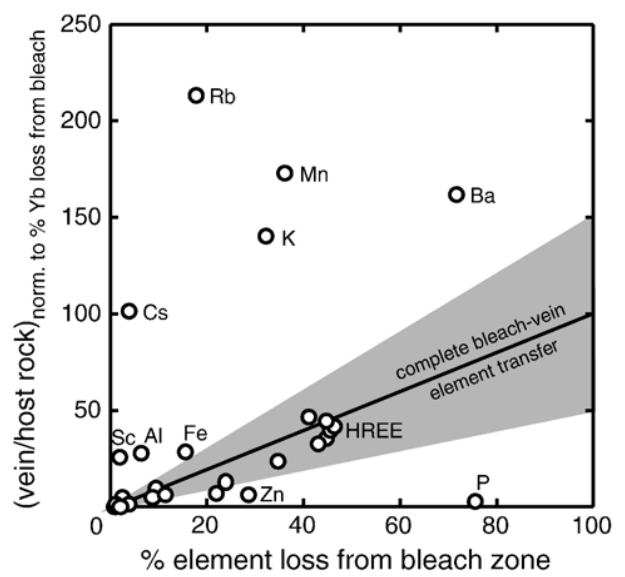

Fig. 9. Plot of percentage elemental loss from bleach zone versus vein composition double normalised to the host rock and then to percentage $\mathrm{Yb}$ loss from the bleach zone. The thin solid line represents complete balance between element loss from the bleach zones and element uptake in the veins (based on conservation of $\mathrm{Yb}$ ). The grey shaded field represents $\pm 50 \%$ of complete mass balance. Note the over enrichment of LILE, and $\mathrm{Mn}$ in the veins and $\mathrm{P}$ depletion from the bleach zones and veins.
Thompson, 1978). Based on the major mineral assemblage (garnet, omphacite and amphibole) and calculated metamorphic temperatures, we expect that the host rock underwent conditions of peak metamorphism similar to $1.9 \mathrm{GPa}$ and $600{ }^{\circ} \mathrm{C}$, as proposed for other rocks of the PEM (Carson et al., 1999). Major and trace element zoning of garnet is typical of garnet growth during prograde metamorphism up to eclogite-facies. HREE and $\mathrm{Mn}$ concentrate into the earliest-forming garnet, whereas the enrichment of MREE on the garnet rims is expected to be due to breakdown of MREE-rich minerals such as titanite and lawsonite at the final stages of the blueschist to eclogite-facies transition (Spandler et al., 2003).

\subsection{Origin of the bleach zones and veins}

Many aspects of the mineral and bulk-rock geochemistry of the bleach zones and host rock are similar, which indicates that the bleach zones represent metasomatized host rock. Moreover, similarities in temperature calculations and oxygen isotope compositions of the bleach zones and host rock implies that bleach zone formation occurred at to prior to peak metamorphism, and the fluids associated with metasomatism were buffered by the host rock. Depletion of garnet components is evident from the low proportion of garnet in the bleach zone and the significant depletion of garnet-hosted elements such as $\mathrm{Mn}, \mathrm{Fe}, \mathrm{Y}$ and HREE (Table 5; Fig. 6). Likewise, metasomatism is invoked to explain the lack of phengite and the low $\mathrm{K}$ and $\mathrm{Ba}$ contents of the bleach zones. By contrast, the bleach zones have high concentrations of $\mathrm{CaO}, \mathrm{Na}_{2} \mathrm{O}, \mathrm{S}, \mathrm{Li}$ and $\mathrm{V}$. These elements are hosted by omphacite (Table 4), which is the dominant mineral in the bleach zones, and sulfides. 
The spatial associations of the bleach zones and veins also indicate that these rocks have a direct genetic relationship. The mineral assemblage and calculated metamorphic temperatures of the veins indicate formation was not related to the influx of fluids during retrograde metamorphism of the PEM. The coarse grain size and lack of inclusions in minerals of the veins indicates that they were grown from a fluid phase rather that by metamorphic reaction of pre-existing grains. Furthermore, the veins do not parallel the rock foliation and therefore are not regarded to be veins originally formed prior to metamorphism.

On petrologic and geochemical grounds it is clear that the garnet components $\left(\mathrm{Fe}_{2} \mathrm{O}_{3}, \mathrm{Al}_{2} \mathrm{O}_{3}, \mathrm{Y}, \mathrm{HREE}\right)$ and much of the LILE in the veins were sourced from the surrounding bleach zones. However, perhaps the most striking feature of the veins is the unusual chemical zoning of the garnet porphyroblasts (Fig. 3). Progressively core to rim zoning of Mn and HREE in the vein garnets is similar to the zoning of the host rock garnets and is indicative of garnet growth over an extended $P-T$ range. Based on prior petrologic work from the PEM (Yokoyama et al., 1986; Clarke et al., 1997) and temperatures calculated from garnet rim compositions, the vein and host rock garnets are expected to have grown during prograde metamorphism over a temperature range of $\sim 400{ }^{\circ} \mathrm{C}$ to $\sim 600^{\circ} \mathrm{C}$. However, the sector zoning and fine intergrowth structures revealed by the $\mathrm{Mg}$ and Ca X-ray maps (Fig. 3) indicates that garnet growth in the veins proceeded under very different chemical conditions than in the host rock and confirms that the veins are not metamorphosed precursor veins. There are very few reports of garnet from regional metamorphic rocks with sector-zoning, irregular oscillations or fine intergrowths similar to that documented here (Yardley et al., 1996; Kohn, 2004; Meth and Carlson, 2005). Nonetheless, in all these cases, the sector zoning or intergrowths are primarily caused by variations in $\mathrm{Ca}$ concentrations, as observed here. These garnets grow as single grains (Yardley et al., 1996), but there have been no definitive explanations of how they develop. They are unlikely to result from exsolution on cooling as the known immiscibility solvus for garnet only occurs in very pyrope-rich compositions (Wang et al., 2000). In this case we attribute the unusual zoning features to processes related to garnet growth from fluid, possibly during episodic microcracking/sealing within the veins or supersaturation of the fluid.

The outer rim of the vein garnets is compositionally and texturally distinct from the bulk of the garnet grains and thus represents a separate stage of garnet growth in the veins (Fig. 3). The relatively high temperature of crystallisation and high $\mathrm{Mg}$ and low Mn contents of this garnet domain indicates formation at close to peak metamorphic conditions from a fluid of different composition to that responsible for growth of the bulk of the garnet grains.

\subsection{Source of fluids and mass transfer calculations}

The transport of garnet (HREE, Y, Mn, Fe) and phengite (LILE) components from the bleach zone into the veins represents significant mass transfer. Zoning in the vein garnets indicates that this mass transfer took place over an extended period during prograde metamorphism. Nevertheless, the oxygen isotope composition of the bleach zone and veins remained in equilibrium with the host rock during metamorphism (Fig. 7), which implies that the fluid composition was locally sourced or internally buffered. Mass balance based on isocon calculations indicates that considerable mass $(\sim 10 \%)$ has also been added to the bleach zones and externally derived components comprise a significant portion of the veins (Figs. 8 and 9). As the solute contents of low $T$ $\left(<600{ }^{\circ} \mathrm{C}\right)$ fluids are expected to be low (Spandler et al., 2003; Manning, 2004), this mass addition would require input from large flux of externally derived fluids; a premise not supported by the rock buffered oxygen isotope characteristics. Possible solutions to this conundrum are; 1) the oxygen isotope composition of the external fluid was close to $10 \%$ to be in equilibrium with the host rock, or 2) mass balance based on the isocon method is inaccurate.

A clear indication of the external fluid source comes from the trace element composition of phengite from the veins. The vein phengite is distinctly different from the host-rock phengite and cannot be accounted for by trace element depletion from the bleach zones, as shown in Fig. 4. Instead, the vein phengite has compositions that are intermediate between phengite from the host rock and phengite from pelitic rocks of the PEM. This implies that two sources supplied components for phengite growth in the veins; 1) leaching of the host rock to form the bleach zones, and 2) external fluids derived from pelitic rocks. Pelitic rocks are LILE and silica rich, so pelite-derived fluids would be expected to have relatively high LILE and silica contents and could account for much of the phengite and quartz in the veins. Whole rock isotopic data for two PEM pelites plotted against Garlick Index (Fig. 7) indicates pelite-derived fluids would have $\delta^{18} \mathrm{O}$ compositions of $12 \%$. This is consistent with $\delta^{18} \mathrm{O}$ fluid compositions of $11.5-15 \%$ calculated from the isotopic composition of minerals 
(quartz, phengite) from PEM sediments as reported by Black (1974). Therefore, pelite-derived fluids had a significantly different isotopic composition that the fluids responsible for bleach zone and vein formation. While it is clear that some external pelite-derived fluid was involved in vein formation, the flux of this fluid must have been sufficiently low as to leave no detectable oxygen isotopic imprint on the veins or bleach zones.

A low flux of external fluid may be adequate to explain phengite compositions and high LILE content of the veins, but is difficult to reconcile with extensive mass gain to the bleach zones as suggested from the isocon calculations. Furthermore, the similar trace element characteristics of bleach zone and host rock omphacite (Table 4) do not support infiltration of external components to grow omphacite in the bleach zones. The most apparent feature of bleach zone and vein formation is the transfer of garnet components such as HREE. The coarse rutile in the veins is also interpreted to have precipitated directly from a fluid. Isocon calculations require assumptions on the immobility of an element, yet in this case, HREE and HFSE, elements that are considered to be among the most immobile in metamorphic fluids (Brenan et al., 1994; Stalder et al., 1998; Green and Adam, 2003; Rubatto and Hermann, 2003), have clearly been mobilised during vein formation. Therefore, the assumption of immobility of a reference element may be incorrect in this circumstance. For mass balance calculations, we have assumed immobility of LREE due to the very low LREE contents of the vein sample. In eclogite-facies rocks LREE are chiefly hosted by accessory phases such as monazite or allanite (Hermann, 2002; Spandler et al., 2003). Accessory minerals often form very coarse crystals or are concentrated into clusters within high- $P$ veins (e.g., Nadeau et al., 1993; Franz et al., 2001; Rubatto and Hermann, 2003). Therefore, appropriate proportions of all accessory minerals in the veins may not have been sampled as only a small amount of vein material was used for chemical analysis. In this case, the low concentration of LREE in the veins may an artefact of the small sample size used and so they may be inappropriate as reference elements for mass balance calculations. Nonetheless, we maintain that the concentration of most other major and trace elements determined for the veins are representative, as these elements are hosted by the major minerals phengite, quartz and garnet.

In sum, the mass addition to the bleach zone as indicated by isocon calculations is inconsistent with isotopic constraints. Isocon calculations have been used successfully to determine mass transfer in a range of metasomatic and vein systems (e.g., Markl et al., 2003; Molina et al., 2004), but in this case we cannot confidently assign an immobile reference element and hence accurate mass balance calculations cannot be made. We stress that careful scrutiny of element immobility is required prior to mass transfer calculations based on the isocon method. Nonetheless, elemental excesses in the veins plotted in Fig. 9 are normalised to HREE mass balance, and so are independent of the isocon calculations. Therefore, it is clear that a significant component of the LILE in the veins was derived externally.

\subsection{A model for vein formation}

Despite the mass balance problems, petrologic and geochemical characteristics of the veins and bleach zones verify that garnet and phengite components have been transferred from the bleach zone into the veins. A very large fluid flux was required to mobilise the large quantity of highly insoluble elements (Fe, Mn, HREE, Y, HFSE) into the veins. The excesses of LILE together with the phengite trace element compositions (Fig. 4) indicate involvement of external sedimentary-derived fluids in vein formation. Nonetheless, the oxygen isotope signatures of the veins and bleach zones confirm that the bulk of the fluid responsible for vein formation was buffered by the host rock. Moreover, garnet zoning indicates vein growth occurred over an extended period during prograde metamorphism.

Based on these constraints, the following model for formation of the bleach zones and veins is proposed. During prograde metamorphism associated with subduction of altered oceanic crust, the mafic host rock progressively transformed from lawsonite blueschist to eclogite; a premise consistent with the metamorphic history of the eclogite-facies rocks from New Caledonia (Clarke et al., 1997; Spandler et al., 2003). Fluid is released by the breakdown of lawsonite, chlorite, and other hydrous minerals and garnet porphyroblast growth is initiated. Advection of this fluid within the rock during continued prograde metamorphism is regarded as the major cause of vein and bleach zone development, although the specific processes of vein growth are uncertain. Mass transfer by diffusion through a stagnant fluid within fracture zones is unlikely to produce the complex chemical zoning and intergrowth features of the vein garnet porphyroblasts. By contrast, fluid alteration driven by periodic microcracking/sealing in and around garnet porphyroblasts may explain the usual chemical features of the garnets. Due to the high viscosity contrast between garnet and other rock matrix 
minerals (e.g., mica, amphibole, and omphacite), garnet porphyroblasts and their surrounding pressure shadows may be favoured sites for episodic microfracturing and associated fluid influx (Lister et al., 1986; Masuda and Mizuno, 1995). Nucleation kinetics and chemical diffusion gradients in the fluid will promote plating of garnet adjacent to the microfracture, as well as growth of other phases such as quartz and mica (Lister et al., 1986). With continued burial over time, episodic microfracturing and mineral precipitation close to the garnet porphyroblasts effectively establishes a local circulation of fluid which generates the high effective fluid flux required to mobilise significant mass (including relatively insoluble HREE and HFSE) into the veins. The adjacent wall rock will become highly depleted in garnet and phengite to form the green bleach zones. The prolonged growth of garnet in the veins also accounts for their pronounced Mn and HREE zoning profiles (Figs. 3 and 5). At this stage, all of the fluid is locally sourced from the mafic host rock with no external fluid input. Similar processes have been invoked to explain mineral segregations in other eclogite-facies terranes (Philippot, 1993; Nadeau et al., 1993; Rubatto and Hermann, 2003).

Although closed system fluid alteration is invoked to explain the bulk of the vein and bleach zone formation, there is also evidence for a small influx of external pelite-derived fluids. This fluid is proposed to have introduced additional LILE and Mn into the veins and possibly additional $\mathrm{Ca}, \mathrm{Na}, \mathrm{Li}, \mathrm{S}$ and $\mathrm{V}$ into the bleach zones. The nature and timing of the external fluid flux is poorly constrained, but we speculate that growth of the outer Mg-rich rims of the vein garnets may be related to the influx of this external fluid at close to peak metamorphic conditions. If this is the case, the through flow of external fluid represents the final stage of vein growth and may correspond to mesoscale (metres to tens of metres) interconnection of veins followed by fluid draining.

In summary, the quartz-garnet-phengite veins and surrounding bleach zones are primarily generated by closed-system circulation of fluid derived from mineral dehydration during blueschist to eclogite-facies metamorphism. However, the veins were also infiltrated by a low flux of external pelite-derived fluid, possibly at the final stage of vein formation.

\subsection{Implications for fluid recycling in subduction zones}

Seafloor altered oceanic crust in subducting slabs is widely regarded as an important source of $\mathrm{H}_{2} \mathrm{O}$ for arc magmas. However, major dehydration of subducting mafic rocks is thought to occur during conversion from blueschist to eclogite beneath the fore-arc regions $(50-80 \mathrm{~km})$ of subduction zones (Liu et al., 1996; Schmidt and Poli, 1998). Therefore, it is difficult to reconcile metamorphic dehydration of mafic rocks in the slab to fluid fluxing of the mantle wedge at sub-arc depths $(90-150 \mathrm{~km}$; Tatsumi and Eggins, 1995).

Surprisingly, many exhumed ultra-high $\mathrm{P}$ terranes are relatively undeformed (Stöckhert, 2002), which indicates that large sections of subducting slabs may escape significant shearing and deformation, at least to depths of $150 \mathrm{~km}$. Fluid connectivity studies of such rocks indicate that fluid-filled pores will not form interconnecting networks, and hence the fluid may remain trapped within the rock (Watson and Lupulescu, 1993; Mibe et al., 2003). This is consistent with petrologic and isotopic studies that advocate extremely limited fluid migration in subducted slabs (Philippot, 1993; Nadeau et al., 1993; Barnicoat and Cartwright, 1995; Miller et al., 2001; Scambelluri and Philippot, 2001).

The PEM represents the upper portions of a slab subducted to depths of around $70 \mathrm{~km}$ (Spandler et al., 2004a). The mafic host rock examined in this paper is relatively undeformed and represents metamorphosed altered MORB. Therefore, this rock is ideal for studying fluid release and migration in relatively undeformed subducting oceanic crust. The model for vein formation described above requires that fluid produced by mineral dehydration during the blueschist to eclogite transition is at least partly trapped in the host mafic rock to allow extensive local fluid circulation and development of the veins. This implies that the timing of slab dehydration may be significantly offset from fluid migration out of the slab. Instead, fluids trapped within the slab are carried to deeper levels where they reach higher temperatures and hence a greater element solubility potential. It should be noted that these processes require the host rock to remain relatively undeformed during subduction, as fluid migration is likely to be rapid in actively deforming metamorphic rocks. Nonetheless, many eclogite-facies terranes have undergone little deformation (Stöckhert, 2002), so retention of free fluid in undeformed mafic rocks may be important for delivering fluid to deeper levels in subduction zones.

Localised fluid circulation could eventually lead to the formation of extensive vein systems that have distinctly different rheological properties than their surrounding host rock. Such vein systems would be favourable sites for large-scale fracture propagation 
(Fletcher and Merino, 2001), which may represent a significant seismic event and would allow through-flow and draining of fluids from the rock. Similar processes may explain the late influx of external fluid proposed for the vein system described in this paper. In subduction zones, these processes could be critical for fluid escape from the slab and the transfer of slab volatiles and trace elements into the source regions of arc magmas.

As a final point, we stress that the chemical composition of the veins described in this paper is clearly controlled by the dominant minerals present in the veins. Many elements that are considered to be fluid immobile (HREE, HFSE) have high concentrations in the high- $P$ veins examined here and from other eclogite-facies terranes (Philippot and Selverstone, 1991; Franz et al., 2001; Rubatto and Hermann, 2003). We concur with Philippot (1993) and Rubatto and Hermann (2003) that these high- $P$ veins represent precipitates or cumulates of extensive fluid-rock interaction and therefore caution against the use of vein compositions to directly infer fluid compositions (e.g., Becker et al., 1999; Gao and Klemd, 2001).

\section{Conclusions}

Garnet-quartz-phengite veins and associated bleach zones in mafic eclogite from the PEM represent products of complex fluid-rock interactions under high- $P$ conditions. Major mass transfer from the bleach zones to the veins was achieved by prolonged circulation of fluids that were derived locally from the host rock by prograde mineral dehydration. Fluid circulation provided the high fluid flux necessary to transfer relatively immobile elements, such as HREE, into the veins. An additional but small flux of external fluid also introduced some elements (chiefly LILE) into the veins, mostly likely at the final stage of vein formation. The most significant implication of this work is the recognition that mineral dehydration and fluid migration in subducting oceanic crust may be significantly decoupled, allowing fluid to be transported to deeper levels of subduction zones.

\section{Acknowledgments}

This work was supported by the Australian Research Council and the Swiss National Science Foundation. We thank Kevin Faure for the stable isotope analyses, Marco Scambelluri, Gordon Lister and Steve Cox for comments and constructive criticisms at the early stages of this work and J. F. Molina and Geoff Clarke for constructive reviews.

\section{References}

Aitchison, J., Clarke, G.L., Meffre, S., Cluzel, D., 1995. Eocene arccontinent collision in New Caledonia and implications for regional southwest Pacific tectonic evolution. Geology 23, 161-164.

Barnicoat, A.C., Cartwright, I., 1995. Focused fluid flow during subduction: oxygen isotope data from high-pressure ophiolites of the western Alps. Earth Planet. Sci. Lett. 132, 53-61.

Bebout, G.E., 1995. The impact of subduction-zone metamorphism on mantle-ocean chemical cycling. Chem. Geol. 126, 191-218.

Becker, H., Jochum, K.P., Carlson, R.W., 1999. Constraints from highpressure veins in eclogites on the composition of hydrous fluids in subduction zones. Chem. Geol. 160, 291-308.

Black, P.M., 1974. Oxygen isotope study of metamorphic rocks from the Ouégoa District, New Caledonia. Contrib. Mineral. Petrol. 47, 197-206.

Brenan, J.M., Shaw, H.F., Phinney, D.L., Ryerson, F.J., 1994. Rutileaqueous fluid partitioning of $\mathrm{Nb}, \mathrm{Ta}, \mathrm{Hf}, \mathrm{Zr}, \mathrm{U}$, and $\mathrm{Th}$ : implications for high field strength element depletions in islandarc basalts. Earth Planet. Sci. Lett. 128, 327-339.

Carson, C.J., Powell, R., Clarke, G.L., 1999. Calculated mineral equilibria for eclogites in $\mathrm{CaO}-\mathrm{Na}_{2} \mathrm{O}-\mathrm{FeO}-\mathrm{MgO}-\mathrm{Al}_{2} \mathrm{O}_{3}-\mathrm{SiO}_{2}-$ $\mathrm{H}_{2} \mathrm{O}$; application to the Pouébo Terrane, Pam Peninsula, New Caledonia. J. Metamorph. Geol. 17, 9-24.

Carson, C.J., Clarke, G.L., Powell, R., 2000. Hydration of eclogite, Pam Peninsula, New Caledonia. J. Metamorph. Geol. 18, 79-90.

Castelli, D., Rolfo, F., Compagnoni, R., Xu, S., 1998. Metamorphic veins with kyanite, zoisite and quartz in the Zhu-Jia-Chong eclogite, Dabie Shan, China. Isl. Arc 7, 159-173.

Clarke, G.L., Aitchison, J.C., Cluzel, D., 1997. Eclogites and blueschists of the Pam Peninsula, NE New Caledonia; a reappraisal. J. Petrol. 38, 843-876.

Clayton, R.N., Mayeda, T.K., 1963. The use of bromine pentafluoride in the extraction of oxygen from oxides and silicates for isotopic analysis. Geochim. Cosmochim. Acta 27, 43-52.

Fitzherbert, J.A., Clarke, G.L., Powell, R., 2003. Lawsoniteomphacite-bearing metabasites of the Pam Peninsula, NE New Caledonia: evidence for disrupted blueschist- to eclogite-facies conditions. J. Petrol. 44, 1805-1831.

Fletcher, R.C., Merino, E., 2001. Mineral growth in rocks: kineticrheological models of replacement, vein formation, and syntectonic crystallisation. Geochim. Cosmochim. Acta 65, 3748-3773.

Franz, L., Romer, R.L., Klemd, R., Schmid, R., Oberhaensli, R., Wagner, T., Shuwen, D., 2001. Eclogite-facies quartz veins within metabasites of the Dabie Shan (eastern China); pressuretemperature-time-deformation path, composition of the fluid phase and fluid flow during exhumation of high-pressure rocks. Contrib. Mineral. Petrol. 141, 322-346.

Ganor, J., Matthews, A., Schliestedt, M., 1994. Post-metamorphic low $\delta^{13} \mathrm{C}$ calcite in the Cycladic complex (Greece) and their implications for modelling fluid infiltration processes using carbon isotope compositions. Eur. J. Mineral. 6, 365-379.

Gao, J., Klemd, R., 2001. Primary fluids entrapped at blueschist to eclogite transition: evidence from the Tianshan meta-subduction complex in northwestern China. Contrib. Mineral. Petrol. 142, $1-14$.

Garlick, G.D., 1966. Oxygen isotope fractionation in igneous rocks. Earth Planet. Sci. Lett. 1, 361-368.

Grant, J.A., 1986. The isocon diagram - a simple solution to Gresens equation for metasomatic alteration. Econ. Geol. 81, 1976-1982.

Green, T.H., Adam, J., 2003. Experimentally-determined trace element characteristics of aqueous fluid from partially dehydrated mafic 
oceanic crust at $3.0 \mathrm{GPa}, 650-700{ }^{\circ} \mathrm{C}$. Eur. J. Mineral. 15, 815-830.

Gresens, R.L., 1967. Composition-volume relationships in metasomatism. Chem. Geol. 2, 47-65.

Hacker, B.R., Peacock, S.M., Abers, G.A., Holloway, S.D., 2003. Subduction factory: 2. Are intermediate-depth earthquakes in subducting slabs linked to metamorphic dehydration reactions. J. Geophys. Res. 108 (Art. No. 2030).

Hermann, J., 2002. Allanite: thorium and light rare earth element carrier in subducted crust. Chem. Geol. 192, 289-306.

Humphris, S.E., Thompson, G., 1978. Hydrothermal alteration of oceanic basalts by seawater. Geochim. Cosmochim. Acta 42, $107-125$

Kohn, M.J., 2004. Oscillatory- and sector-zoned garnets record cyclic (?) rapid thrusting in central Nepal. Geochem. Geophys. Geosyst. 5 (Art. no. Q12014).

Lister, G.S., Boland, J.N., Zwart, H.J., 1986. Step-wise growth of biotite porphyroblasts in pelitic schists of the western LysCaillaouas massif (Pyrenees). J. Struct. Geol. 8, 543-562.

Liu, J., Bohlen, S.R., Ernst, W.G., 1996. Stability of hydrous phases in subducting oceanic crust. Earth Planet. Sci. Lett. 143, 161-171.

Manning, C.E., 2004. The chemistry of subduction-zone fluids. Earth Planet. Sci. Lett. 223, 1-16.

Markl, G., Abart, R., Vennemann, T., Sommer, H., 2003. Mid-crustal metasomatic reaction veins in a spinel peridotite. J. Petrol. 44, 1097-1120.

Masuda, T., Mizuno, N., 1995. Deflection of pure shear viscous flow around a rigid spherical body. J. Struct. Geol. 17, 1615-1620.

Maurizot, P., Eberle, J.-M., Habault, C., Tessarollo, C., 1989. Notice Explicative Sur La Feuille Pam-Ouegoa. Bureau De Recherches Geologiques et Minieres, Noumea.

Meth, C.E., Carlson, W.D., 2005. Diffusion-controlled synkinematic growth of garnet from a heterogeneous precursor at Passo Del Sole, Switzerland. Can. Mineral. 43, 157-182.

Mibe, K., Yoshino, T., Ono, S., Yasuda, A., Fujii, T., 2003. Connectivity of aqueous fluid in eclogite and its implications for fluid migration in the Earth's interior. J. Geophys. Res. 108 (Art. No. 2295).

Miller, J.A., Cartwright, I., Buick, I.S., Barnicoat, A.C., 2001. An Oisotope profile through the HP-LT Corsican ophiolite, France and its implications for fluid flow during subduction. Chem. Geol. 178, $43-69$.

Molina, J.F., Poli, S., Austrheim, H., Glodny, J., Rusin, A., 2004. Eclogite-facies vein systems in the Marun-Keu complex (Polar Urals, Russia): textural, chemical and thermal constraints for patterns of fluid flow in the lower crust. Contrib. Mineral. Petrol. 147, 487-504.

Nadeau, S., Philippot, P., Pineau, F., 1993. Fluid inclusion and mineral isotopic compositions $(\mathrm{H}-\mathrm{C}-\mathrm{O})$ in eclogitic rocks as tracers of local fluid migration during high-pressure metamorphism. Earth Planet. Sci. Lett. 114, 431-448.

Peacock, S.M., 1993. The importance of blueschist to eclogite dehydration reactions in subducting oceanic crust. Geol. Soc. Amer. Bull. 105, 684-694.

Pearce, N.J.G., Perkins, W.T., Westgate, J.A., Gorton, M.J., Jackson, S.E., Neal, C.R., Chenery, S.P., 1997. A compilation of new and published major and trace element data for NIST SRM 610 and NIST SRM 612 glass reference materials. Geostand. News. 21, $115-144$

Philippot, P., 1993. Fluid-melt-rock interaction in mafic eclogites and coesite-bearing metasediments: constraints on volatile recycling during subduction. Chem. Geol. 108, 93-112.
Philippot, P., Selverstone, J., 1991. Trace-element-rich brines in eclogitic veins: implications for fluid composition and transport during subduction. Contrib. Mineral. Petrol. 106, 417-430.

Putlitz, B., Matthews, A., Valley, J.W., 2000. Oxygen and hydrogen isotope study of high-pressure metagabbros and metabasalts (Cyclades, Greece): implications for the subduction of oceanic crust. Contrib. Mineral. Petrol. 138, 114-126.

Ravna, E.J.K., 2000. The garnet-clinopyroxene $\mathrm{Fe}^{2+}-\mathrm{Mg}$ geothermometer: a updated calibration. J. Metamorph. Geol. 18, 211-219.

Rawling, T.J., Lister, G.S., 2002. Large-scale structure of the eclogiteblueschist belt of New Caledonia. J. Struct. Geol. 24, 1239-1258.

Rubatto, D., Hermann, J., 2003. Zircon formation during fluid circulation in eclogites (Monviso, Western Alps): implications for $\mathrm{Zr}$ and $\mathrm{Hf}$ budget in subduction zones. Geochim. Cosmochim. Acta 67, 2173-2187.

Scambelluri, M., Philippot, P., 2001. Deep fluids in subduction zones. Lithos 55, 213-227.

Schliestedt, M., Matthews, A., 1987. Transformation of blueschist to greenschist facies rocks as a consequence of fluid infiltration, Sifnos (Cyclades), Greece. Contrib. Mineral. Petrol. 97, 237-250.

Schmidt, M.W., Poli, S., 1998. Experimentally based water budgets for dehydrating slabs and consequences for arc magma generation. Earth Planet. Sci. Lett. 163, 361-379.

Selverstone, J., Franz, G., Thomas, S., Getty, S., 1992. Fluid variability in $2 \mathrm{GPa}$ eclogites as an indicator of fluid behaviour during subduction. Contrib. Mineral. Petrol. 112, 341-357.

Spandler, C.J., Hermann, J., Arculus, R.J., Mavrogenes, J.A., 2003. Redistribution of trace elements during prograde metamorphism from lawsonite blueschist to eclogite facies; implications for deep subduction-zone processes. Contrib. Mineral. Petrol. 146, 205-222.

Spandler, C.J., Hermann, J., Arculus, R.J., Mavrogenes, J.A., 2004a. Geochemical heterogeneity and element mobility in deeply subducted oceanic crust; insights from high-pressure mafic rocks from New Caledonia. Chem. Geol. 206, 21-42.

Spandler, C.J., Hermann, J., Rubatto, D., 2004b. Exsolution of thortveitite, yttrialite and xenotime during low temperature recrystallization of zircon from New Caledonia, and their significance for trace element incorporation in zircon. Am. Mineral. 89, 1795-1806.

Spandler, C.J., Rubatto, D., Hermann, J., 2005. Late CretaceousTertiary tectonics of the southwest Pacific; insights from $\mathrm{U}-\mathrm{Pb}$ SHRIMP dating of eclogite-facies rocks from New Caledonia. Tectonics 24, TC3003.

Stalder, R., Foley, S.F., Brey, G.P., Horn, I., 1998. Mineral-aqueous fluid partitioning of trace elements at $900-1200{ }^{\circ} \mathrm{C}$ and $3.0-5.7$ GPa: new experimental data for garnet, clinopyroxene, and rutile, and implications for mantle metasomatism. Geochim. Cosmochim. Acta 62, 1781-1801.

Stöckhert, B., 2002. Stress and deformation in subduction zones: insights from the record of exhumed metamorphic rocks. In: de Meer, S., Drury, M.R., de Bresser, J.H.P., Pennock, G.M. (Eds.), Deformation Mechanisms, Rheology and Tectonics: Current Status and Future Perspectives. Spec. Publ.-Geol. Soc. Lond., vol. 200, pp. 255-274.

Sun, S.S., McDonough, W.F., 1989. Chemical and isotopic systematics of oceanic basalts; implications for mantle composition and processes. In: Saunders, A.D., Norry, M.J. (Eds.), Magmatism in the Ocean Basins. Spec. Publ.-Geol. Soc. Lond., vol. 42, pp. 313-345.

Tatsumi, Y., Eggins, S.M., 1995. Subduction Zone Magmatism. Blackwell, Cambridge. 211 pp. 
Taylor, S.R., McLennan, S.M., 1985. The Continental Crust: Its Composition and Evolution. Blackwell, Oxford. 312 pp.

Wang, L., Essene, E.J., Zhang, Y., 2000. Direct observation of immiscibility in pyrope-almandine-grossular garnet. Am. Mineral. $85,41-46$.

Watson, E.B., Lupulescu, A., 1993. Aqueous fluid connectivity and chemical transport in clinopyroxene-rich rocks. Earth Planet. Sci. Lett. 117, 279-294.

Widmer, T., Thompson, A.B., 2001. Local origin of high pressure vein material in eclogite facies rocks of the Zermatt-Saas Zone, Switzerland. Am. J. Sci. 301, 627-656.

Widmer, T., Ganguin, J., Thompson, A.B., 2000. Ocean floor hydrothermal veins in eclogite facies rocks of the Zermatt-Saas Zone, Switzerland. Schweiz. Mineral. Petrogr. Mitt. 80, 63-73.

Yardley, B.W.D., Condliffe, E., Lloyd, G.E., Harris, D.H.M., 1996. Polyphase garnets from west Ireland: two-phase intergrowths in the grossular-almandine series. Eur. J. Mineral. 8, 383-392.
Yokoyama, K., Brothers, R.N., Black, P.M., 1986. Regional eclogite facies in the high-pressure metamorphic belt of New Caledonia. In: Evans, B.W., Brown, E.H. (Eds.), Blueschists and Eclogites. Mem. Geol. Soc. Amer. , pp. 407-423.

Zack, T., Foley, S.F., Rivers, T., 2002. Equilibrium and disequilibrium trace element partitioning in hydrous eclogites (Trescolmen, Central Alps). J. Petrol. 43, 1947-1974.

Zheng, Y.-F., 1993a. Calculation of oxygen isotope fractionation in anhydrous silicate minerals. Geochim. Cosmochim. Acta 57, 1079-1091.

Zheng, Y.-F., 1993b. Calculation of oxygen isotope fractionation in hydroxyl-bearing silicates. Earth Planet. Sci. Lett. 120, 247-263. 